\section{BOOKK REVIIEIS}

\section{Shaw (C.A.)}

Euripides: Cyclops. A Satyr Play. London and New York: Bloomsbury Academic, 2018. £,18.99. ISBN 978-1474245807

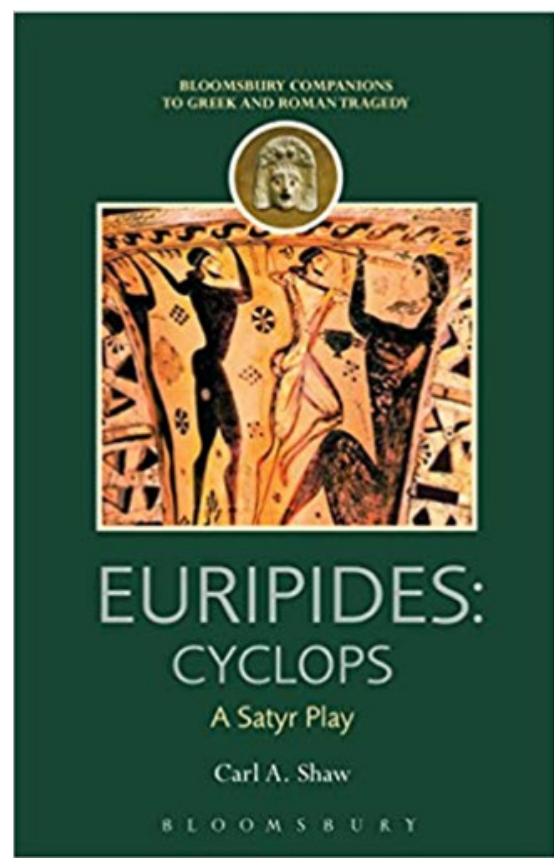

Professor Shaw has produced an account which is not only enjoyable to read, but also gives keen insights into Euripides' play and Greek theatre in general. His sections upon the Dionysia (pp.1-3) and satyrs (pp.3-20) are suitable for teachers and sixth form students alike. In addition to this his discussion of Cyclops' position within the context of $5^{\text {th }}$ Century Athenian culture and history provides fascinating reading for any Classicist with an interest for the period, especially literary history. Throughout, black and white images of vases are provided as useful evidence and the book itself is a fine object, well-bound in hardback with a clear font, wide margins, nice paper; it looks good on the shelf.
In Chapter Two he gives an overview of the play's plot providing literary and character analyses including its setting near Mount Etna, considering the limitations of the outdoor theatre of Dionysus. His analysis shows Euripides' use of Homer's Odyssey, especially playing with the theme of ' $\alpha \nu \delta \rho \alpha$ from the

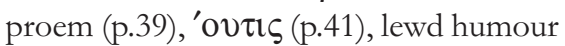
(pp.42-43; pp.47-49), the reputation of Helen (p.44), sophistic comments upon divinity (pp.51-52), issues of plot (e.g. that the Cyclops here does not block off the cave's entrance (p.54)) and the more civilised nature of Polyphemus (p.55). This chapter would be of great help for a student writing a project upon this play, having read it in translation.

Chapters 3 and 4 are more advanced, accessible and fascinating. Shaw challenges the idea that drama was 'nothing to do with Dionysus' showing that this play is all about him. Indeed, he shows how Satyr drama was very selfconscious and metatheatrical: 'Each year, there were tragedies and comedies at the festival, but the choruses of these genres continually changed. No matter what myth was presented in a satyr play, though, there was (almost) always a chorus of satyrs' (p.69). Thus, satyr drama is very self-referential, working under the aegis of 'take myth, add satyrs, observe result'; therefore Cyclops gives us a way into understanding the Athenian understanding of Dionysiac religion. Pages 75-85 provide an interesting discussion of xenia, barbarians, philosophy and links the play with the Sicilian disaster. Sections of this would be good for students studying A-Level Classical Civilisation and Ancient History, if they wanted to add a novel ancient source to their arsenal. Chapter 4 goes a step wider and discusses Alcestis' and Cyclops' links with the Decree of Morychides (440-436), outlawing the direct and personal mocking attacks which were a vital feature of Old Comedy. The discussion of this decree is brilliant for any A-Level teacher of Classical comedy. Shaw concludes that Cyclops was meant to be the best satyr play of all time, being self-referential in the extreme. $\mathrm{He}$ continues to show how this is our earliest, contemporary commentary upon Homer's Cyclops myth (useful again for Classical Civilisation, pp.97-102) and the Homeric Hymn to Dionysus (pp.102-104). These would need careful distilling for students. Pages 109-118 are a treat for Classicists as Shaw argues how Cyclops may be an example of Euripides actually satirising his own writing by have Cyclops make reference to the earlier plays of the tetralogy (Helen, his lost Andromeda, Iphigenia amongst the Taurians).

Furthermore, he suggests how Sophocles' Philoctetes and Aristophanes'

Thesmophoriazusae in turn make gentle satiric reference to Cyclops which may have become a classic of Athenian drama. Food or maybe wine for thought for anyone who enjoys $5^{\text {th }}$ Century intertextuality.

\section{A.K.J. Carroll, Saint Olave's Grammar} School, Kent

\section{Finglass (P.J.)}

Sophocles: Oedipus the King. (Cambridge Classical Texts and Commentaries 57). Cambridge:

Cambridge University Press. 2018.

Cased. £135. ISBN 978-1-108-41951-2

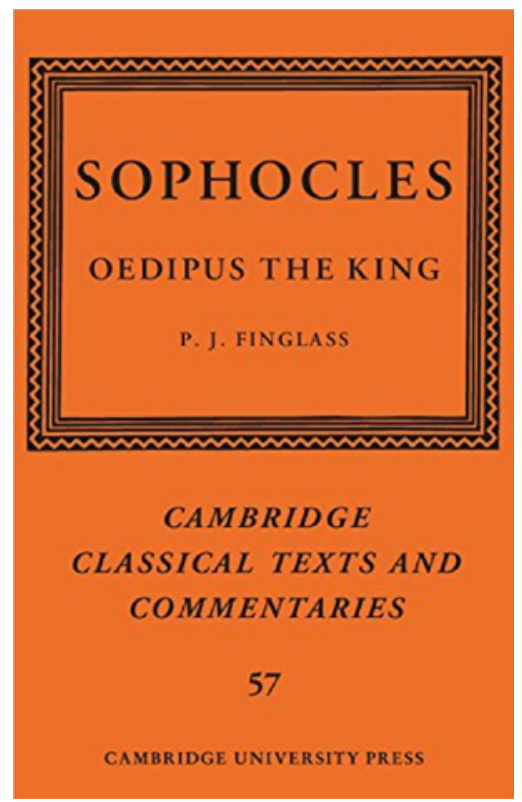

In the newest version of Sophocles' OT since Dawe's 2006 revision of his Cambridge 'green and yellow' text, Professor Finglass offers the first editio maior in any language since Jebb's in 1883. Comprised of a new text and apparatus - the author counting 56 substantive differences between his text and LloydJones and Wilson's revised Oxford Classical Text - this sizable volume offers nearly 100 pages of introduction 
and some 450 pages of commentary. Time will be the best judge of Professor Finglass' emendation of a corrupt manuscript tradition (if not Finglass himself: his predecessors Lloyd-Jones and Wilson have revised their OCT once, and Dawe edited the text five times); this review will focus on the didactic qualities and accessibility of what may well be a landmark edition.

Following his editions of Electra (2007) and Ajax (2013) Professor Finglass treads carefully in the footsteps of Richard Claverhouse Jebb, who published editions of these plays in the same sequence. Published between 1883-96, Jebb's editions of Sophocles are among few works of 19th century scholarship that retain currency in the $21 \mathrm{st}$. In the path of such a grandee, it is not only Finglass' phenomenal knowledge of the play's exegetic tradition that will ensure this edition's legacy, but his consideration for the varied requirements of today's readership.

From the introduction, Finglass' spare and lucid prose is a treat to read, and there is much to appeal to teachers of Classical Civilisation, instructors in Greek language and the dramaturgically inclined - as well, of course, as those whose interest in Greek is primarily philological. In an impressively thorough introduction, F. takes us on a guided tour of the Oedipus myth's transformations in antiquity (13-40), pauses to situate $O T$ amid subgenres of tragedy (40-82), and poses pertinent questions arising from very recent discourse, such as Edith Hall's blog post about $O T$ and vase painting (85). There are some thoughtful inclusions about the play in performance, such as a table of role division (11) and great attention is paid to entrances, exits and other matters of production throughout.

Like Jebb, F. has kept the use of Latin to a minimum; textual abbreviations and sigla are generally confined to the apparatus, enabling the reader of the commentary to concentrate on the Greek itself. Matters of textual criticism are explained with remarkably little jargon in the commentary, which is neatly divided into numbered episodes and stasima. At the beginning of each such section is a précis of the action, with comment on its relationship to the whole. As we get stuck into the commentary itself, we find a thoughtful design providing relief for weary eyes: where Jebb experimented with various layouts in his editions of Sophocles, with notes (in English) beneath his Greek text and a Loeb-style translation opposite, F. opts for a compromise that will keep purists happy without forgetting those of us grateful for a little help: leaving only an apparatus beneath an unadorned Greek text, Professor Finglass fully reprints and translates all Greek lemmata in the commentary, enabling less confident Hellenists - or even, feasibly, those with no Greek at all — to make the most of this edition. This simple measure enables the reader to savour the commentary, uninterrupted by the flicking back and forth required by Cambridge 'green and yellows' and Bristol Classical texts. I commend the book in particular for its remarkably thorough indices (of Greek words, and of subjects).

F. has come under fire from reviewers in the past for not dwelling more on reception - albeit hardly the primary task of an editor of Sophocles' Greek - and for those interested in performance, he points readers in the direction of Macintosh's brilliant Oedipus Tyrannus (2009). For those whose definition of reception includes the history of scholarship however, F. comes into his own, opening up an intellectual history that can often feel impenetrable. As Steiner observed in his Antigones (1984, 216) commentary can be latent with unendingness. The breeding of exegesis out of previous exegesis is menacing in so far as it occludes the primary text.' Far from adding to the exegetic pileup, Professor Finglass' selective approach does much to demystify and declutter a vast canon of critical heritage. The omission of the Paris school from the bibliography will disappoint fans of structuralism, but such matters of preference aside, generations to come will no doubt be grateful for such a concise, inclusive, thoughtfully written commentary.

The only less fortunate similarity to Jebb's editions of Sophocles — whose cost A.E. Housman once lamented is the price-tag: not yet available in paperback, the hardback comes in at a whopping $f^{135}$, a price most school (and some university) libraries' budgets will balk at. Despite this, it would take a great deal to rival this volume as a definitive edition of $O T$, so roll on the paperback — or perhaps, to take Jebb's tradition further still, an abridged edition for schools?

\section{Peter Olive, Royal Holloway, University of London, Westminster Tutors, London SW7}

\section{Murnaghan (S.) (ed., trans.)}

\author{
Medea New York; London: W. W. \\ Norton \& Company 2018. £7.95. \\ ISBN: 9780-393265-453.
}
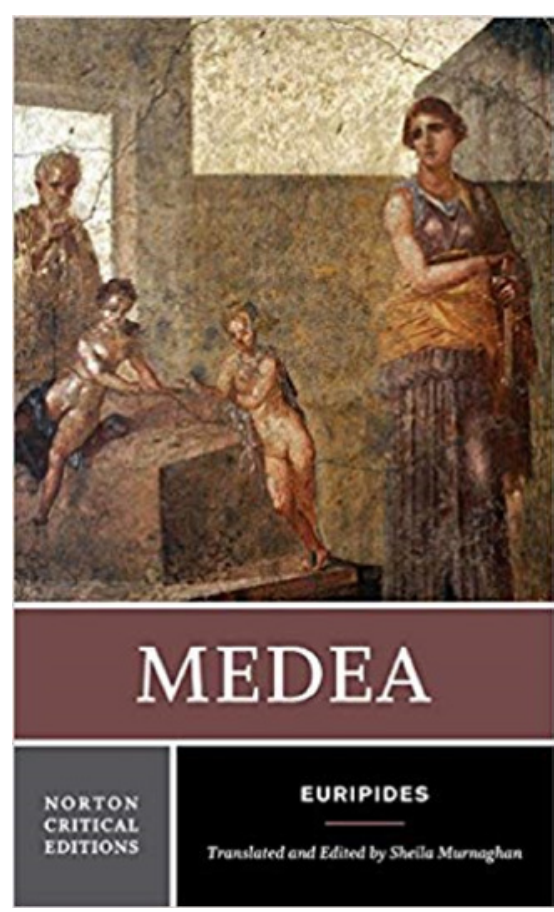

This book is a part of the series Norton Critical Editions which aims to present students with some of the 'great' works of literature from across the canon. It seeks to be a translation based on current scholarship while giving some wider context to the play. Murnaghan has a good pedigree as Professor of Greek at the University of Pennsylvania and indeed is currently working on a 'Green and Yellow' edition of Sophocles' Ajax. But what can another translation into English bring?

Murnaghan's translation itself is based on Mastronarde's text in the 'Green and Yellow' series. It follows the Greek closely (the line numbers correspond to the Greek) but is not afraid to read as if written in natural English. It takes out some of the repetitions and idioms of the Greek, but avoids modern colloquialisms which would quickly date. It also has the 
benefit of clarity, helped by sensible line divisions and ordering of clauses and phrases. In some other translations, I find myself reading the words but then having to ask myself what they actually mean. This is not the case with Murnaghan's translation. At the same time, it is very easy to see how the translation reflects the Greek. This is no easy feat, and makes an enjoyable read for those new to Greek drama while satisfying those of us who are concerned that the words of Euripides should not misrepresented in a concern for accessibility.

As well as her translation, the book contains her introduction and two further sections entitled Contexts and Criticism. Her introduction, amounting to 14 pages, covers the areas of the myth before Euripides, the play's production and afterlife as well as the relationship of myth and society and a consideration of the character of Medea. Contexts and Criticism gives some additional readings. Contexts presents three extracts over ten pages to place the play within the context of thought of the ancient world: from the Oeconomicus of Xenophon on the nature of marriage; the Argonantica by Apollonius of Rhodes, in Book 3 where Medea debates with herself her dilemma of whether to abandon her parents; and Seneca's Medea, at the point where she has just killed one of her sons and prepares to kill the other. There are also three elements to the Criticism section, which comprises secondary literature: Pat Easterling's 1977 article entitled The Infanticide in Euripides' Medea; Helene Foley's chapter Medea's Divided Self (2001) from Female Acts in Greek Tragedy; and Edith Halls' Divine and Human in Euripides' Medea (2014). The selections are interesting and well-judged. I particularly liked the primary sources taking the reader from the well-known Euripides to lesser-known authors. Choosing just three secondary sources is asking a lot, but these three cover sensible areas and are approachable to those thinking about the play for the first time. With a total of 45 pages, these give the reader something substantial to get their teeth into. For those whose curiosity is stimulated, she ends with a two-page Selected Bibliography for investigating the play further.

For those studying the text for A-level, the translation used on the examination paper is Harrison's in the series Cambridge Translations from Greek.
Drama. This has detailed notes facing each page of translation and is an excellent way of understanding the significance of what is said, line-by-line. Murnaghan has a great deal more background material, which can help students achieve a richer experience of the context of the play. The clarity of the translation means that this would be particularly good to give to a student who wanted to read a play on their own that they were not going to be examined on. It would also be particularly helpful to give to students in Year 12 considering reading Classics or Classical Civilisation at university to see how the subject widens out beyond detailed reading of the text.

\section{Clive Letchford, University of Warwick}

\section{Mulroy (D.) (edd., trans.)}

Aeschylus: The Oresteia. Agamemnon, Libation Bearers, and The Holy Goddesses. Pp. xxx + 234. Madison, WI: University of Wisconsin Press, 2018. Paper, US\$19.95 (Cased, US\$39.95). ISBN: 978-0-299-31564-1

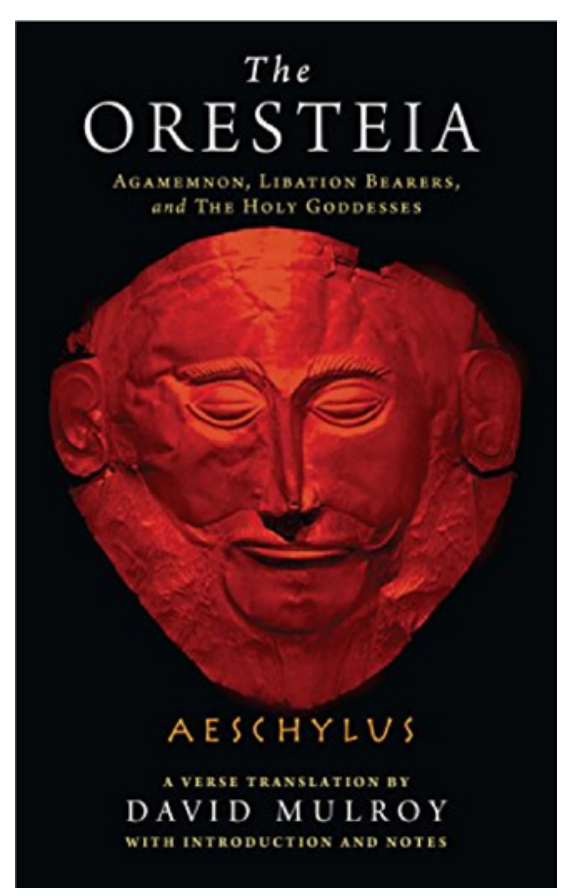

Mulroy has approached translation of the Oresteia with a focus on recreating that alien concept, to the modern ear, of formalism, which he achieves through iambic pentameter and 'some end rhyme' (pp.xii-xiii). The translation, which Mulroy hopes will be 'distinguished' by this approach, is then disrupted as the editor follows up on loose ends in terms of translation, context, and other points of interest. These diversions arguably detract from Mulroy's effort to create a book specifically for the reader.

To judge this work on Mulroy's own terms, we should examine the quality of his translation. Each of the three plays is studded with creative and lively renderings of the Greek. From his Agamemnon: 'Just honor me as human, not divine. // Our language makes the differences between fine woven works and foot towels clear.' (p.42, vv.925-927); from his Libation Bearers: 'Send Justice forth to help, or else let us // secure the wrestling grip they used on you, // if you intend to win the second match.' (p.108, vv.497-499); and, from his Holy Goddesses, an evocative image: 'You'll retch and vomit up the frothy blood // and clotted gore you've sucked from mortal men.' (p.151, vv.183-184). Mulroy is happy to depart from stiff translation, and in the choral odes especially, employs phrases which are derived or expanded from the Greek, with pleasing outcomes, such as this from his Holy Goddesses: 'We choose to level houses // revelling in sin, // when Ares turns domestic, // and someone murders kin.' (p.160, vv.354-356).

Given Mulroy's priority of beauteous, English formalism, that his verses might occasionally depart too far from the Greek is to be understood, though I contend that they do, often. Take these verses from his Agamemnon: 'Except one man who didn't wish to sail: // Odysseus. He became my favorite horse,' (p.39, vv.841-842), which hardly functions as a metaphor when deprived

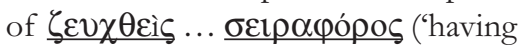
been yoked, the trace horse...').

Nevertheless, even on Mulroy's own terms as above, there are too many lines which read as facile, or at least in the wrong register. For instance, from his Agamemnon: 'She strikes. He falls where waters wash // his wounded body clean, // a basin built for taking baths, // a clever death machine.' (p.54, vv.11261129), which elides $\pi \dot{\varepsilon} \pi \lambda$ ol $\sigma \mathrm{l}$ ('the robe'), misinterprets $\mu \eta \chi \alpha v \eta \dot{\mu} \mu \alpha \tau$ (here, 'devious' or 'hidden' perhaps) of the Greek, but worst of all, fails to capture the deranged nature of Cassandra's prophesying. The register and tone suffer again in Libation Bearers, when Electra could not seem more apathetic as she segues between a solemn religious rite, and a moment of high drama; she has 
discovered a clue of her estranged brother's presence: 'Since Father has had his muddy offerings now, / / I'd like to share another bit of news.' (p.92, vv.164-166). And when Apollo describes the return of Agamemnon in the Holy Goddesses, the lightness of language results in a phrase too bland for a god, testifying in an Athenian court no less: 'The king had just returned from waging war // and doing rather well.' (p.173, vv.631-632).

Alongside the text, the volume has much to offer, although the intended audience of the peripheral information is not always clear. Mulroy uses the Preface (pp.ix-x) and the Introduction (pp.xi-xv) to, slightly haphazardly, discuss themes, historical context, the authorial voice, and the idiosyncrasies of his edition (i.e. naming the wife of Agamemnon 'Clytaemestra' with good reason, and labelling the Chorus Leader 'Coryphaeus' with none). These pique the interest but it is not clear why some information is fronted in the introduction, and other pertinent or useful material is relegated to the seven appendices at the end (pp.193-231). For the reader, Appendices 1 and 3 , which contain synopses and the mythological background, are most useful, while Appendices 2 and 4, on Aeschylus, and the historical and political context, may suit the school student. Appendix 7 addresses the theatrical context and staging, which is also inconsistently included by Mulroy in the body of his translation; at times he asserts a certain staging, beyond what is necessary for an understanding of the text, such as the tentative direction in the Holy Goddesses: 'the Ghost of Clytaemestra appears. Perhaps she rises from behind the navel stone' (p.146), but does not do this often enough to properly scaffold a production.

Appendices 5 and 6 concern the technicalities of Mulroy's renaming of the Eumenides to the Holy Goddesses (a compelling argument), and a detailed discussion of metre, both Greek and English. I would be surprised if either of these would be accessible to anyone below undergraduate level. Taken as a whole, the appendices, as well as the footnoting and bibliography, represent far too varied a selection of information. A trained Classicist may well find themselves distracted or bored by footnotes explaining, for instance, who Zeus is (pp.4-5), but more concerningly, Mulroy's target audience, that is an interested reader of English, may be baffled by interjected comments on textual corruptions and conjectured reconstructions, which too often bar a straightforward reading. Mulroy has the capacity to write for either audience, but he must choose which.

I repeat that this volume has much to offer. The three translations are often lively and the metre does not restrain bold and beautiful language. The wealth of information contained in the footnotes and appendices, evidence of the depth of research, stimulates engagement with these texts at any level. However, it will be incumbent on any reader to read selectively, or for the teacher to select appropriate extracts. Furthermore, reading this edition alongside other translations, and indeed the Greek text, will illuminate obscurity, throw occasional bland passages into relief, and ultimately achieve the best understanding of the Oresteia.

\section{Edmund Gazeley, Merchant Taylors' School, Northwood}

\section{Sheehan (S.)}

A Guide to Reading Herodotus' Histories. Pp. xii +316 , ills. London: Bloomsbury Academic, 2018. Paper, £22.99. ISBN: 978-1-4742-9266-5.

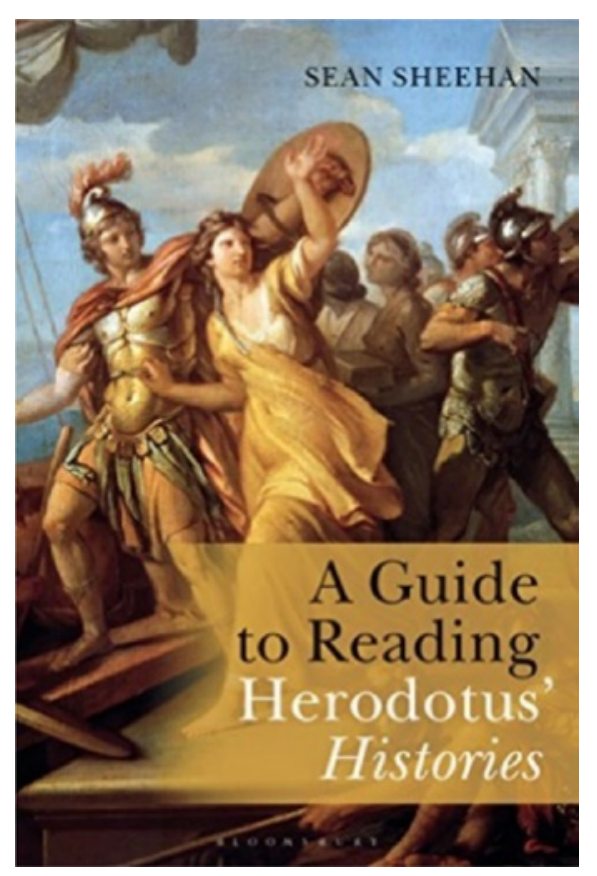

I was very pleased to have come across this book just as I was preparing to teach Herodotus again after an interval of several years. I had taught a core History course to first-year students using the Histories, but now would be leading an independent study by more advanced students. I would say that this guide would be of more use to the more advanced students.

The reading toward which Sheehan would guide us is complex, flexible, and sophisticated. It draws upon Herodotean scholarship from Felix Jacoby to Tom Holland (though Seth Benardete appears as 'Bernadette'), folds in the anthropology of Levi-Strauss and the metahistory of Hayden White; and invokes such figures as Walter Benjamin and the Bakhtinian. He even reaches as far afield as Finnegans Wake for 'Hairyoddities', Joyce's gloss on the tendency of the Father of History to be a purveyor of fables. On the other hand, he is very concerned to make the Histories accessible to those who would look to him for guidance. The Guide includes a series of diagrams - which he calls 'boxes'- which outline the logoi, lay out the plots and plot the themes, and mobilise the quotes. These are always clear, and clearly connected to the more discursive explication.

Sheehan's Guide is divided into a series of chapters representing 'Approaches to Herodotus', followed by 'Commentary', which proceeds straightforwardly through each of the nine books of the Histories. These Approaches are themselves straightforward enough: The Form of the Histories; Herodotus the Historian; The Histories as Literature, among others; but a comparison of these with the chapter titles of similar introductory books about Herodotus might remind readers of this one just how approachable the Histories are. James Romm writes of 'The Man and the Work', but also of 'The Downfall of Greatness' and 'The Kingdom of Culture'. John Gould, whose work Sheehan seems to particularly approve of, has written about 'Enquiry' and 'Social Memory', 'Mapping Other Worlds', and, in the end, 'Reading Herodotus'. I once thought of writing such a book myself; it would have begun with 'What is History for Herodotus?' and ended with 'Herodotus 'Today'. These books are made of those approaches, but have not the Commentary that comprises the greater part of Sheehan's Guide. It is rather more like J. L. Myres' Herodotus: The Father of History, which does not appear in Sheehan's bibliography. But if that is outdated, Sheehan updates it. It is no longer necessary to convince readers that Herodotus was indeed the Father of 
History; but it is now necessary to convince people to read the Histories.

We may take as an example of

Sheehan's approaches the one that considers 'Herodotus the Historian'. Herodotus is 'The Father of History', because what he wrote was history, and no one wrote it before he did. As early as Thucydides and Plutarch, critics have questioned whether Herodotus makes proper use of his sources; but Sheehan argues that he used the sources available to him; and if he sometimes seems too credulous, at other times he is explicitly critical. The historie are critical on 'an epistemological sliding scale' (p.17) that accounts for the relative credibility of his various sources. Herodotus has a sense of history, recent and distant; he knows what can be known, and what can't. He can distinguish between what he knows from what he hears, and what he knows from what he sees. His use of folk tales and oral traditions (where he may seem most uncritically credulous) sheds light on how history works. 'The conversation between Solon and Croesus', for instance, 'may be an invention originating in oral tradition, but it functions as a paradigm for underlying themes of importance to Herodotus' view of history' (p.20).

As for the commentary on the nine books, let us take Book Two, since that is where I am at the moment with my Herodotus students. Book Two is all about Egypt. It is less digressive than Book One, but is itself a digression. Herodotus writes about Egypt because the Persian King Cambyses is planning an invasion; he can write about Egypt because Greeks have been there for centuries, and he went there himself. He writes about the history of Egypt, but also the geography, ethnography, and even zoology of the country. He is always interested in religion, but is here particularly interested in distinguishing religion from history, even though most of his sources are Egyptian priests. They are the keepers of extensive records covering thousands of years; but though they have kept records, they have not made inquiries. And Herodotus, in Egypt, relies as much on what he sees as on what they say.

This is a good Guide to Reading Herodotus' Histories, in that it is also a good guide to writing about it. Neither the Approaches nor the Commentary explicitly address the writing that the readers are likely to do; but a teacher might readily turn it to those purposes. In its organisation, its mix of paraphrase, summary, and interpretive observations and claims,and its deployment of quotes from both Herodotus and Herodotean scholars, Sheehan can show students how such stuff is done.

When I first taught the Histories, Herodotus was hot. The 9/11 attacks had reactivated the ancient narrative of enmity between East and West. The Zach Snyder film 300 brought the Persian Wars into popular culture. Tom Holland first came to Herodotean prominence with Persian Fire. I set up a Google Alert for Herodotus, and every day would get an email with at least half a dozen links to news articles and blog posts. The Landmark Herodotus was published, as were Travels with Herodotus by Ryszard Kapuscinski and The Way of Herodotus by Justin Marozzi. Anthony Pagden's Worlds at War began precisely where Herodotus did. That moment seems to have passed; and yet Herodotus is no less worth reading. I hope that Sheehan's Guide might inspire a new generation of students to read their Histories.

\section{Barry Knowlton}

\section{Tanfield (C.) (ed.)}

Cicero Philippic II: A Selection. Pp. viii + 179, maps. London: Bloomsbury Academic, 2018. Paper, £16.99. ISBN: 978-1-350-01023-9.

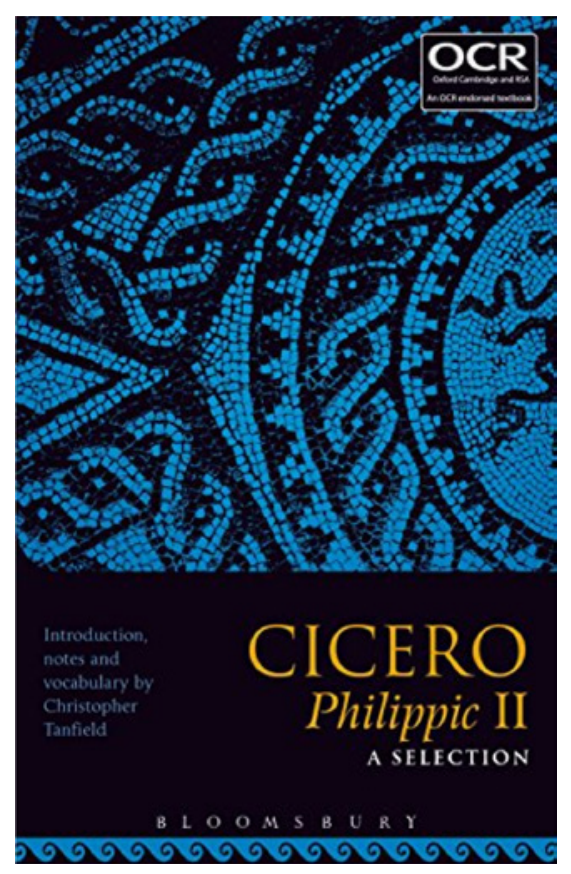

This work, blue-liveried and with the OCR stamp of endorsement, joins the growing collection of companion editions for current and forthcoming OCR set texts. The ever-present issue of these editions is utility; the text is virtually unchanged from the 1918 OCT edition ( $v$. p.34), and this book will very soon be outdated (these sections of Philippics II will be the set text for examination in 2020-2021). As such, one might expect a substantial commentary, as well as a decent array of corresponding information to support the teacher and student. In this, Tanfield delivers on the latter, but not the former.

Tanfield provides a meaty introduction to this edition (pp.1-27), which covers historical context, introduction to and classification of classical oratory (which happily does not shy away from a wealth of technical terms), Demosthenes' legacy, a glossary of stylistic features, notes on scansion and clausulae, and a reading list. Here the value of the book is most apparent; not only has Tanfield collated this information effectively (so the teacher doesn't have to), it is also written in an accessible way, clearly with the A-level student in mind. The exemplar paragraph which shows how to tackle rhetorical devices in essay writing is a particular highlight and could easily and usefully be incorporated into a lesson. The introduction thoroughly prepares the student for reading the text with full knowledge of the historical and linguistic hinterland. This is then further supported by the detailed summaries of the non-examined Latin and otherwise prescribed English text, which are excellent and seem to represent the bulk of Tanfield's work, again to the benefit of the teacher (pp.51-53, 69-70, 100).

As for the commentary itself, the content is variable. In its favour, it is peppered throughout with references to Bennett's New Latin Grammar (1918), which takes on the heavy lifting of specific grammatical features; for the purposes of understanding the language, this is a sensible subcontraction to a resource easily found online. The vocabulary list (pp.137-179) is another highly beneficial feature, which will allow the student to work from a single book, if that is desirable. The vocabulary items are also marked with an asterisk if they are also found on the OCR Defined Vocabulary List.

The commentary is also full of small pointers, such as on \91: idem tamen: 'you, however, also...'; quasi fuligine abstersa: Ablative absolute NLG 227 (p.96). The benefit of such useful nudges to an 
A-level student when preparing the text independently is undeniable. However it is for the teacher to decide how much explicit linguistic support is necessary or beneficial outside of the classroom.

In the preface (p.viii), Tanfield acknowledges Ramsey's commentary for its assistance; this is scant indication that a significant portion of this commentary is a paraphrase of Ramsey's edition (Cicero: Philippics (2003, CUP)). For instance, take Tanfield's note on praetextatum in \$44: 'The toga praetexta, a toga bordered with purple to recall the gown worn by the kings of Rome, was what boys wore until, at the age of 15 or 16, they took up the plain white toga virilis' (p.54). Compare this with Ramsey: 'until the age of 15 or 16 when free-born Roman boys donned the plain white toga virilis of manhood, they wore the toga praetexta, which had a purple border recalling the purple gown formerly worn by the kings of Rome.' (Ramsey p.226)

Or take \$89, and 'Tanfield's note on the Capitoline: 'After Caesar's assassination, the conspirators (who had styled themselves 'liberators') walled themselves up on the Capitol, under the guard of D. Brutus's gladiators. Cicero visited them on the night of the 15/16 March to advise that they call a meeting of the senate on the Capitol and take advantage of the disarray among the supporters of Caesar. They failed to do so, and came down after a meeting of the senate on 17 March, called by Antony, had declared an amnesty and Antony had provided his own son as a hostage to the conspirators.' (p.92). Compare this to Ramsey (pp.290-291) and observe that Tanfield has rearranged the clauses and added two minor details.

Though concerning, thankfully such examples are rare, and more often Tanfield gives useful expansion on material that Ramsey passes over more briefly, such as a reference to Caesar's absence from Rome in \$103, which Tanfield glosses with: 'After Pharsalus (June 48 BC Julian date), Caesar pursued Pompey to Egypt. Despite Pompey's murder, Caesar remained there backing Cleopatra VII in her conflict with her brother, Ptolemy XIII, and from December 48 till June 47 was incommunicado, not returning to Rome until October that year.' (p.109). Tanfield also goes on to explain why this reference is pertinent to Cicero's point, thereby saving both student and teacher from following up references and reading lists for single facts. By contrast Ramsey just gives the dates of Caesar's absence, and doesn't even say where he was (p.313).

This edition offers much in the way of support to both student and teacher. The quality of the introductory material is excellent and contains everything needed for an A-level student to tackle both the reading of and writing about the text. The value of the edition is however significantly undermined by the commentary, which is derived from Ramsey to no small extent, with the most significant modifications being the omission of explanation of linguistic features beyond A-level, and the addition of simple grammatical information. While the value of OCR editions is in comprehensive coverage of the set text and therefore 'peace of mind', it becomes much harder to justify the cost of copies for each student when the teacher could as easily pull the 'Green and Yellow' and the Loeb (2009) from the shelf (both of which have their own, quite detailed introductions), and employ selectively, as necessary for the students.

\section{Edmund Gazeley, Merchant Taylors' School, Northwood}

\section{Godwin (J). (ed.)}

Horace Odes: A Selection London: Bloomsbury Academic, 2018. £12.99 ISBN: 978-1-5013-2422-2

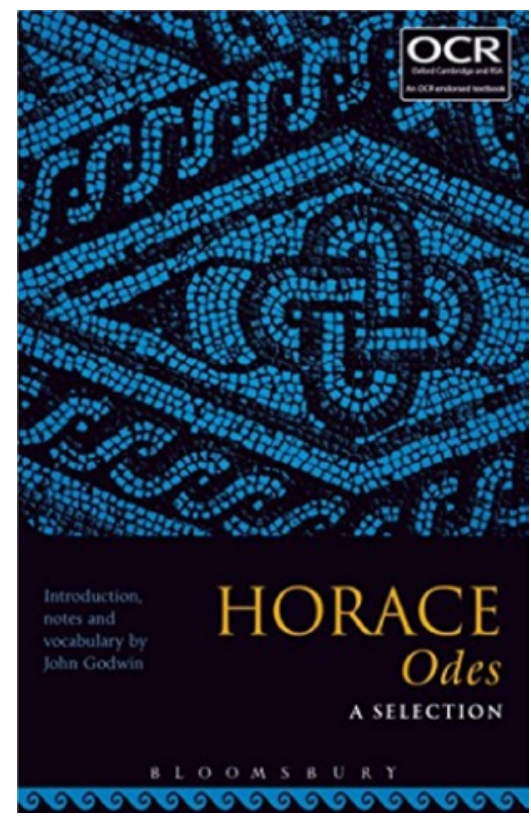

It does not seem all that long since the AQA A-level specification included all six of the 'Roman' odes of Horace, the first six poems of Book III.

Nowadays we must be content to teach - at least for narrow examination purposes - the four odes $(2,3,4 \& 6)$ specified by OCR.

To this end, Godwin has given us an edition which has been carefully and successfully pitched at sixth-form level. Beginning with a short Introduction, including crucially 'Horace and Augustus', Godwin gives the background to the focus on Parthia and memories of Crassus' disastrous defeat at Carrhae in 53 BCE, as well as summarising the likely intention of Horace in referring to Philippi where he had been on the 'wrong' side. The poet's revolutionary act in merging public concerns with (originally Greek) lyric metres is also well brought out.

The fact that all four of the specified poems are in Alcaics renders the section on metre very short; perhaps a little more on the rules for determining the length of a given syllable - as in the OCR/Bloomsbury edition of Aeneid XI - would have been desirable.

When it comes to the commentary, Godwin is unfailingly clear and helpful, assuming (rightly, I think) a bit more knowledge of (e.g.) case usage than does the companion OCR/Bloomsbury edition of Cicero's Philippic II. His great care, not to be confused with the fussiness one sometimes encounters, is shown in items like his discussion of the choice between bibit/bibet in Ode 3, line 12 .

Godwin's thoughts on Ode 6 begin with a masterly section including background on the moral and social legislation of Augustus; and when we get to the dedecorum pretiosus emptor, that quintessentially Horatian characterisation in line 32 , the editor is there with conciseness and clarity.

Although students with access to Williams' (1969) or West's (2002) commentaries on Odes III may be interested to see what light those scholars shed on these fascinating products of the Augustan age, they will be more than adequately served by Godwin's purposewritten work.

\section{Giles Dawson, Freelance Classics teacher, Oxfordshire}




\section{Fratantuono (L). (ed.)}

\section{Tacitus: Annals XVI London and New York: Bloomsbury Academic 2018 £14.99 ISBN: 978-1-350-02351-2}
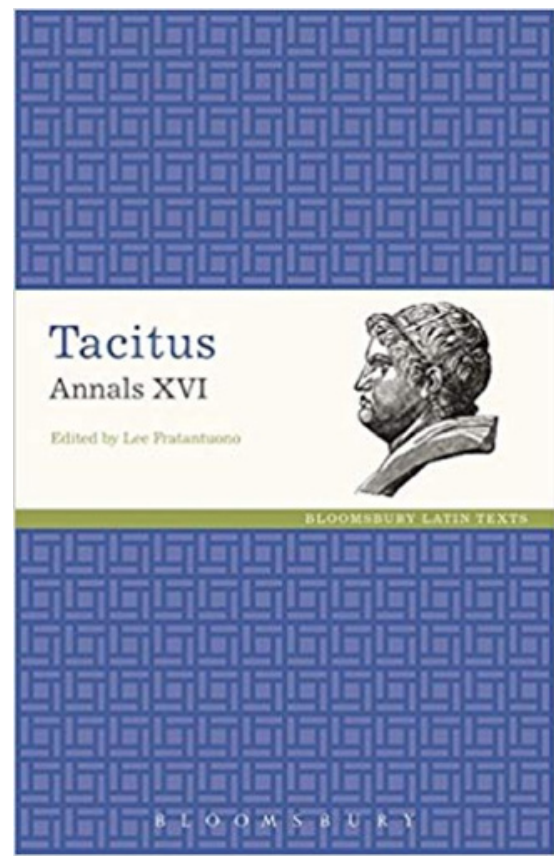

This volume is a very welcome addition to the available editions of Tacitus. Fratantuono rightly notes a 'dearth of editions of Tacitus that are suitable for college and university use' and in particular the lack of separate editions of Book XVI. He provides an affordable, accessible, concise paperback edition which is 'designed to be of particular help to undergraduate students who are approaching the author for the first time' as well as more advanced students. He has aimed to write a traditional 'school commentary', which includes plenty of grammatical help as well as comments on Tacitus' 'program and plan in the Annals' and on links with other authors, especially Virgil and Lucan. This would certainly be a book one could use with sixthformers, should the occasion arise.

Being unfinished or partially lost, Annals XVI is a compassable length and yet manages to include a variety of typically Tacitean material. It deals with parts of the years 65-66, when Nero is becoming ever more tyrannical and unhinged. Money problems are pressing and the first episode concerns Caesellius Bassus, who claims to have found near Carthage a cave containing a huge amount of gold hidden by Dido herself. Nero welcomes this news, entirely taken in, until Bassus' fictions are exposed and he escapes disgrace 'voluntaria morte' - the first of many suicides. Nero's embarrassing insistence on performing comes next, followed by the death of Poppaea. Thereafter begins such a catalogue of deaths that Tacitus himself (in chapter 16) has to apologise for the monotony of horror. Those who know CLC Stage 40 will recognise the fate of Salvius in the description of the death of Thrasea Paetus.

In a brief introduction Fratantuono gives an overview of the Annals, sketches the little we know of Tacitus' own life, briefly surveys his other works and concludes with a discussion of the themes of Book XVI. There are very full references to further reading and other editions for those wishing to explore further.

The text follows and then the commentary. Fratantuono begins each section with an introduction, discussing themes and providing detailed references to relevant books and articles. He then covers such issues as manuscript problems, explanations of characters who appear in the narrative, translations of difficult expressions, grammatical explanation, stylistic points and allusions to other authors; for those interested in reception there are a few references to the film Quo Vadis. In general, the notes are mostly clear, accessible and helpful and would be suitable for sixth-form students.

There follows a dedicated vocabulary, a brief bibliography (far more bibliographical material appears in the commentary itself) and a useful index, mostly of names, but also of themes, concepts, Latin terms etc.

It seems churlish to make complaints about a text which has so many good qualities, but there are some niggles which seem annoying and distracting. The book has been very poorly proof-read. There are words missing from the Latin text: p19 ad accusandum' instead of ad accusandum transgrediens, p28 ipse quamcumque subiret instead of ipse quamcumque sortem subiret, this is inexcusable. There are typos: p94 'grows ever space' for 'grows ever apace', p168 oblectamentum $-I$ (the autocorrect is no doubt to blame here).
The vocabulary is rendered less useful by not being specifically targeted to the text and because it is not complete: no gloss for copia in the difficult phrase si notitiam criminum et copiam diluendi habuisset (p25); an unhelpful gloss for inservire in the phrase hortorum potius amoenitati inservirent' p26 - 'serve, defer to' won't do as a translation.

Fratantuono enjoys his parsing and revels in choice technical terms perhaps this suits the American market - so will tell us that pauca repetenda sunt is 'Gerundive: passive periphrastic' (p95) or that obstitissent is 'Pluperfect subjunctive in a contrary to fact protasis'; sometimes - but not always these comments are clarified with a translation. The grammatical help given is surprisingly uneven; Fratantuono will sometimes explain very basic points (p101) esset: 'Imperfect subjunctive'; (p85) apud: 'once again with its usual accusative object'. However elsewhere Fratantuono offers no help where it would certainly be needed by students: he frequently fails to alert readers to accusative and infinitive in reported speech, even when there is no introductory verb; a very densely argued passage in chapter 26 needs a lot more explication.

Also rather disappointing is the relatively small amount of discussion of style, something which would particularly aid sixth-form students: (p26) postera luce elicits the comment: 'the phrase is not at all common as a temporal marker' - and nothing more. This is surely poetic vocabulary, and indeed probably an echo of Virgil. Expansion on these sorts of points would be welcome.

Conversely Fratantuono digresses freely into seemingly irrelevant asides (p125) explaining that the word basilica had come to refer to Christian churches. More self-discipline in these matters would have freed up space (if that is what he is short of) to expand upon matters germane to the text.

So, all in all, a useful book on many levels and certainly welcome given the availability of commentaries on Tacitus, but one that would have benefitted from a more disciplined and more clearly focused approach. Do buy it, though!

Hilary Walters, Ex of Loughborough Grammar School 


\section{Barton (W. M.). (ed., tranns.)}

The Pervigilium Veneris. $A$ Nen Critical Text, Translation and Commentary. Pp. viii + 153. London: Bloomsbury Academic, 2018. Cased, £85. ISBN: 978-1-350-04053-3.
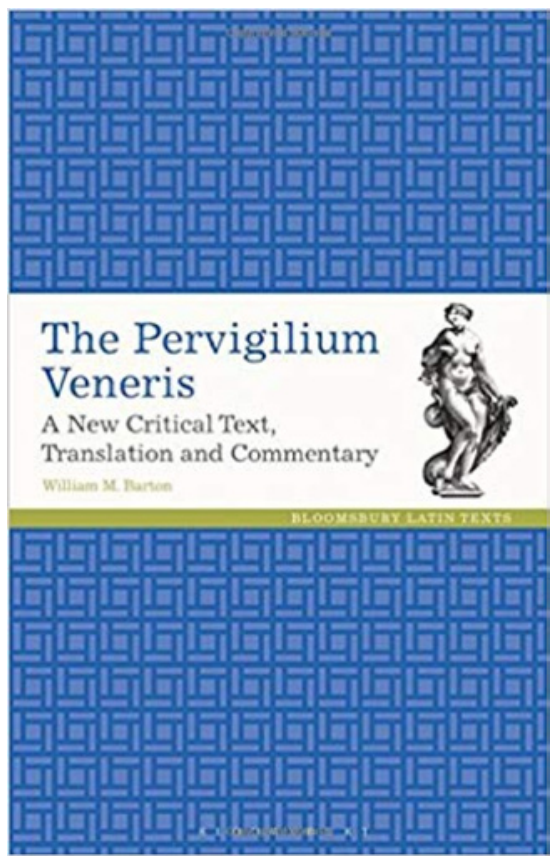

I am probably not alone in having first encountered the Pervigilium Veneris by accident, because it is housed in a Loeb with Catullus and Tibullus. This new critical text with translation and commentary provides a learned and detailed guide to this poetic gem.

The introduction contains sections on the manuscript tradition, the date and authorship of the poem, the metre, the final stanza and interpretation of the poem, and its literary reception. The poem was rediscovered in the $16^{\text {th }}$ century; given its corrupt and challenging manuscript tradition and the uncertainty and debate surrounding its author, the first two sections of the introduction are extremely helpful in summarising the key problems and arguments. The last section is an interesting addition, though it is a shame that the author ends his discussion of the reception of the poem at c. 1800 on the grounds that "the poem's reception after 1809 is (relatively) well known' (p. 49).

Barton provides an English translation alongside his edition of the Latin text, which is presented with a formidable critical apparatus. He charmingly explains that part of the reason for the 'stout apparatus' is that he aims to '[record] the important, interesting and also remarkable readings which make up the history of the poem and its meaning to its numerous readers over the centuries' (p.vii); for Barton, the many variants and conjectures have become part of the life of the poem.

It is in this spirit, too, that the impressive commentary is best understood. There are 61 pages of commentary on this 93-line poem, a substantial part of which is devoted to explaining choices made in the editing. The author regularly explains the rationale behind the choices he has made with clarity and detail. To take one example of very many, in the commentary on line 57/p. 117 (iussit et nudo puellas nil Amori credere), he explains his choice of credere. He first discusses Christine Schmitz's 'attractive alternative reading' of cedere in place of credere, summing up the arguments in favour of it (verbal parallels with Virgil, Eclogues 10.69, and a neat internal logic emphasising the importance of Venus). He then balances this against the fact that all the manuscripts have credere and the fact that credere has been used in connection with Amor before. As well as providing a discussion and a defence of choices in editing, the commentary gives insightful interpretations of the text, for example drawing the reader's attention to the poet's inclusion of the refrain at the end of the poem to create 'a sense of irony and displacement' (p.136). An impressive number of other ancient authors are cited throughout to illustrate parallels or contrasts of theme and language usage. The sheer detail of the commentary can make it feel a little cumbersome, but it seems churlish to complain; the depth of erudition is impressive and illuminating, and the reader gains a much better understanding of the poem through the many explanations and cross-references.

The translation strikes a good balance between being faithful to the Latin and being readable. Faithfulness to the Latin text at times allows some of the most beautiful imagery in the poem to shine through: 'It is she who paints the purpling year with flowery gems, // She who encourages the West Wind's breath // Into their unfolding nodes; she who sprinkles the moistening waters // Of glittering dew that the night breeze leaves behind' (p.65 vv.13-16). On rare occasions, however, the translation can become confusing, for instance later in the same stanza: 'The rose ... Will not be ashamed to reveal her crimson tomorrow, which lay hidden and // Protected beneath a robe of flame, as a bride, from a single knot' (p.67 vv. 23-6).

This is an expensive book, and not one which is scheduled to be a set text. Schools are therefore unlikely to buy a set for a class. From a school perspective, it would be a useful book to recommend to the sixth-form student who wishes to understand more about manuscripts and editing, as the process is so clearly visible in the commentary. Aside from this niche, however, I cannot see that the text would be of much value in the schoolroom; its sometimes intimidating erudition, which recommends it to the more advanced student or scholar, renders it less accessible to the school-aged student.

\section{Maria Bergquist, Merchant Taylors' School, Northwood}

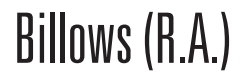

\section{Before and After Alexander: The Legend and Legacy of Alexander the Great. Pp. 336, ills, maps. New Yok and \\ London: The Overlook Press, 2018. \\ Cased, US\$32.95. \\ ISBN: 978-0-715681-7}

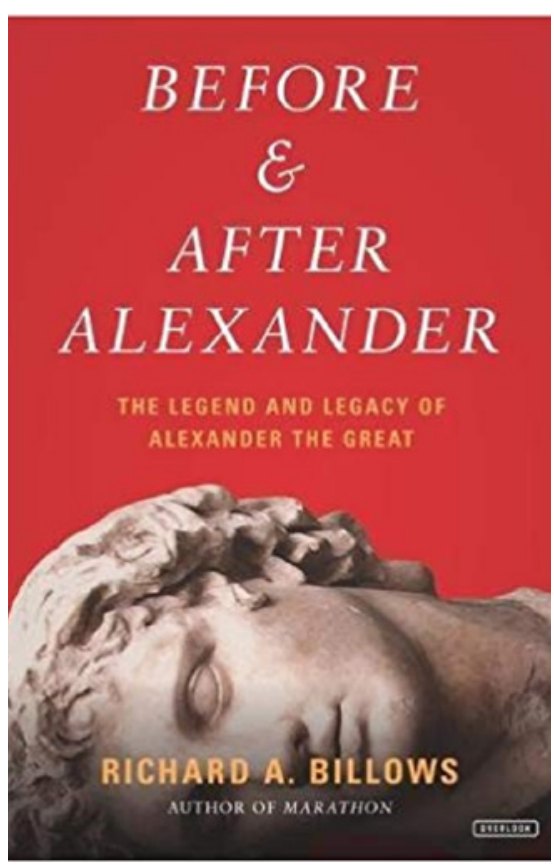

I was intrigued by the premise of this book which does exactly what it says on 
the cover. There seems to be less of an interest in Philip and the Successors than in the rather more dashing, glamorous Alexander himself, so the book-ending of his life in this way fills in the gaps about the influences on him, and his own influence on his successors. It is the method employed by Bettany Hughes in the Hemlock Cup in which she sets out to create a 'Socrates-shaped hole' in Athenian history and Billows appears to have done the same; it works. The earlier parts of the book trace the history of Macedonia, the genealogy, and deeds of the royal family into which Philip was born in 383BC, beginning with their origins in Argos, which led to Alexander being allowed to take part in the sprint race at the Olympic games. There is much to wade through, but the general overview is clear and the chapters on the reorganisation of the Macedonian army explain much about their later successes; in fact, there is a wealth of military detail and analysis of battle strategy which will delight armchair generals and students of warfare alike, (e.g. the introduction of the sarissa, the cavalry wedge and the more elaborate and more disciplined training given to soldiers). This is inevitable when dealing with such a subject, but it does not become boring and the later focus on the battles of Antigonus the One-Eyed and Seleucus, to name but two, is engagingly described. There is no doubt that the author believes that Alexander himself gained his reputation as a result of inheriting a well-trained and supplied army; and in reading about Philip's policy of removing sons from the families of the nobility to train them in his army, one can see the seeds of Alexander's Epigoni. However, it is not only military innovation for which we should remember Philip. When Cleitus the Black accused Alexander of forgetting the debt he owed to his mortal father (Plutarch 50) we understandably think of the army he led, but Philip also undertook a programme of urbanisation as mentioned by Arrian (7.9.2), which resulted in economic development and the ability to fund his reforms. All this served to make Macedonia and its people a force to be reckoned with. Around 40 pages are given over to Alexander himself with a clearly argued section questioning whether he really deserved the name 'Great' and explaining how the legend of Alexander gained traction. The remainder of the book deals with the Successors and gives a clear account of the divisions and conspiracies that characterised this period. As Robin Waterfield points out (Dividing the Spoils 2011), this period deserves to be known better than it is.

The figure of Antigonus the One-Eyed stands out, not only for his long life but for his skill and determination. He makes two appearances in Arrian, the first when he is appointed governor of Phrygia in Book 1 and again in Book 7 when the prophet, Peithagoras, predicts his death in battle. What is not mentioned in Arrian is that the battle in question (Ipsus) was in 301BC and Antigonus was 81 years old. The statesmanship of Ptolemy is also noted as he, to a large extent, stays put in Egypt and founds the dynasty which was to end with Cleopatra VII in 31BC. The final section, however, was for me the most interesting as Billows surveys the Hellenistic legacy. The book does not end with the death of those who had known Alexander but considers the spread of Hellenistic culture in the lands that Alexander conquered and passed through with his Macedonian army. That cities and towns across the Middle East were based on Greek plans drawn up by Hippodamus of Miletus and still survive in modern towns, including New York, is testament to the influence spread by Alexander's campaign. Billows explains how Greek texts, collected in Ptolemy's famous Museion in Alexandria were passed down through the Roman era and how they were preserved by Islamic scholars. This I found to be one of the most fascinating parts of this book. The volume is not overly filled with illustrations but those that are there are well-chosen, and there are maps detailing the various stages covered.

References to ancient sources are clearly signalled and the genealogies, timeline and extensive bibliography will be welcomed by teachers, students, and casual readers. Sadly, Alexander the Great no longer appears on the A-level Classical Civilisation syllabus but there is much of interest here, and the subject matter is well-suited to the OCR Ancient History module 'The Rise of Macedon.'

J M Lashly, Shrewsbury High School

\section{Rhodes (P.J.)}

Periclean Athens Bloomsbury, 2018.

Paper: 144 pages. $\$ 21.56$

ISBN-13: 978-1350014954

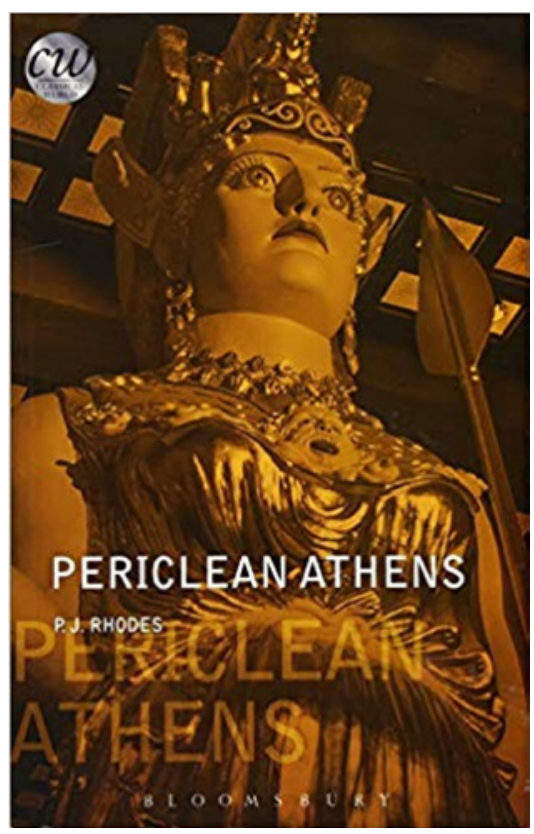

As someone who regularly spends a portion of their week teaching Greek to students on limited time (usually involving an extract of Thucydides at A-Level), for me Rhodes' exploration of Athens during the time of Pericles held instant appeal. Something concise, yet informative, which offers a broader understanding of the period, not just focusing on the conflict between Athens and Sparta, in an easily accessible format, this work has the potential to be of real benefit not only to students of Ancient History or Classical Civilisation, but especially to those studying the Greek language in a compressed fashion and for whom a quick injection of background material could transform their understanding of texts.

Rhodes is pretty clear about his target audience for the work. It is designed explicitly with the 'late school' and 'early university' levels in mind. As such, it is not meant to be a comprehensive, detailed study of the period, but something which will introduce the student to a variety of topics and give them the basics they need to understand the period in an overarching fashion. Similarly, in the space of a work which is quite limited in terms of its physical size (at 104 pages it is strikingly unintimidating), Rhodes does not limit himself only to the Athens of 
Pericles, but permits himself to explore the broader Greek world both in terms of its wider history and its geography. This is a book designed with giving students a flavour and inspiring wider research. He is also very clear that this is not a biography of Pericles and was never intended to be.

The structure which Rhodes has chosen for the work divides the material into six topics: Pericles and His City, Democracy, Empire, Religion and Philosophy, Literature, Art, Architecture (as a single section) and After Pericles. Each of these topics is then divided into sub-topics allowing Rhodes to focus on one particular aspect. For example, Pericles and His City contains a broader exploration of the Greek world (looking to impress upon students that Athens is not Greece and Greece is not the Greek world) and then looks to find Athens' place within wider Greek history and society (Athens and the Greek world). Overviews of religion, modes of government and thoughts on what an ideal Greek citizen might have looked like are all present. Only after this does Rhodes look to find Pericles' place within Athens through an exploration of what we know of his family, its origins and status in the fifth century (Pericles and Athens). Similar approaches are adopted for all the other topics Rhodes has chosen, taking a broad overview and homing in on particular aspects as he moves through the material. For the final topic, After Pericles, Rhodes then revisits each of the four previous topics and explores their development (albeit briefly) into the fourth century and beyond, giving the reader a sense of development throughout the work and an overall understanding of the bigger picture.

Not only are those topics chosen by Rhodes absolutely key to understanding the world of Athens in the fifth century and of great assistance in understanding the Peloponnesian War and Thucydides' account of it, the manner itself in which Rhodes chooses to present these topics should also prove beneficial to the student. Although the work is certainly small enough for a student to take as a whole, the individual topics covered would also function perfectly well when read as stand-alone extracts. In this way the work is flexible enough to be dipped into as required, or for individual topics to be recommended to students who need particularly to know about, for instance, the Delian League or the functioning of Athenian democracy. In addition, it is littered with references to the texts meaning that the eager student will have no trouble accessing the original source material should they wish to. Predictably, much of the focus is on Thucydides, Herodotus, and Plutarch's Pericles, but the selection of texts used by Rhodes to support his work goes considerably further than that and could keep even the most inquisitive student, along with Rhodes' very helpful recommendations for further reading, occupied for a considerable amount of time. There are also a number of useful maps, diagrams and images which will undoubtedly provide valuable context and support to the reader.

As with any work of this size, though, its accessibility can also feel like a weakness. Certain topics work extremely well as an overview and I have no doubt that the sections on democracy and empire would prove valuable to students in understanding their mechanisms and functions. When discussing literature, art and architecture, however, the broad nature of Rhodes' approach means that these topics felt slightly unfulfilling. In particular I hoped for a little more discourse concerning the evolution of such modes of expression in a democratic (yet imperialist) state and the potential influences such a mode of government may have had on the production of art and vice-versa. Similarly, the section on philosophy seems at points to be reduced to a list of philosophers and the philosophical schools of thought which one might have encountered in Athens rather than a discussion of their role in society or how and why these might have emerged at this time and in this place. Oddly, considering the book's size, there was also a noticeable amount of repetition of material when moving from topic to topic.

Despite, however, feeling like Rhodes' overview is, for certain topics, just a little too brief, I think that this book undoubtedly has a tremendous amount going for it. The sheer range of topics touched on and the potential that has to spark further questions and investigations among students makes it an excellent starting point for anyone who wants an introduction to Classical Athens and the wider Greek world in an immediately accessible format whether for use in the classroom or outside of it. I will be recommending this to my students.

\section{Neil Treble, King Edward VI School, Stratford-upon-Avon}

\section{Waterfield (R.)}

Creators, Conquerors, \& Citizens. A History of Ancient Greece. pp. $509+51$, ills, maps. Oxford: Oxford University Press, 2018. Cased, £25, US\$34.95. ISBN: 978-0-19-872788-0

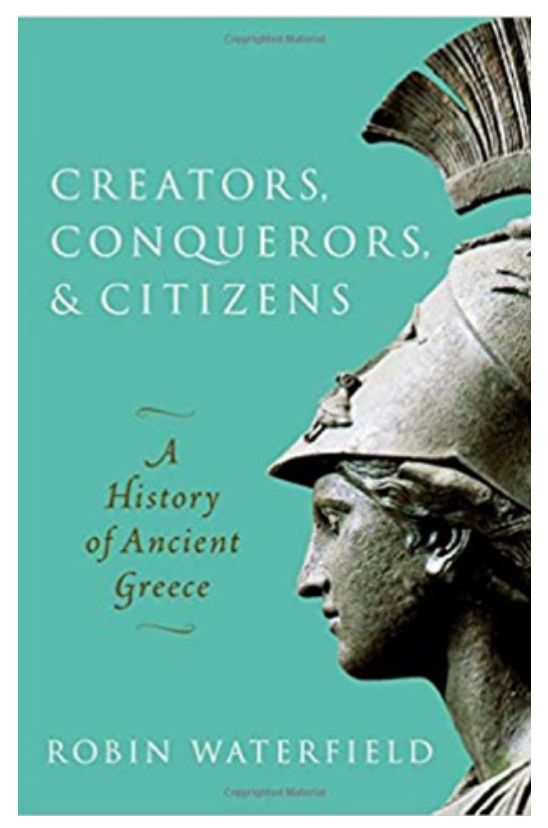

Robin Waterfield's history of Greece achieves the feat of compressing 750 years of the history of innumerable Greek states into 500 or so pages. He brings a sharp forensic analysis to the morass of sources that drives the reader through even the most complex and tortuous of inter-state shenanigans and brings us out the other side unscathed and perhaps, only occasionally, a little bewildered.

Physically, this is an attractive tome which is a pleasure to read. Its typesetting is gracious and approachable and the presentation of information always clear. The black and white illustrations are pertinent and helpful and the maps are indispensable.

The book starts, generously, with two introductions; one to the environmental background and the second to the historical. This is not a book that deals with Mycenae in depth, for example: the focus is on the Greeks, rather than their forebears. Deliberately, as Waterfield explains, the book gives equal weight to the Archaic, Classical and Hellenistic periods and during these periods the action is shared between the various states. At times, as in the case of Syracuse, the narrative structure provides a 
flashback, taking the reader back through the city's geography, culture and history.

The historical narrative is

interspersed with explanations of social and political functions and groups. There are also expositions of cultural aspects, as well as social and personal glosses.

Countless little treasures abound with stories of significant figures' actions and sayings. Tantalising quotations and titbits of information, such as Cleopatra's treatise on medicine, are doled out liberally but rarely gone into in any depth. This all provides a piquant counterpoint to the intensity of the historical narrative.

Many other reviewers use the word 'authoritative' to describe Robin Waterfield's writing. In reading the book, this was a word that resonated throughout. The author's ease in ascribing motivation or asserting the condition of matters without obvious reference to source material is at once impressive and faintly disappointing. At times specific statements are made which caused me to want to understand more and I searched in vain for the evidence to support them. Often, however, interesting quotations and references are provided.

In all historiography there has to be a question of the threshold of evidence to attribute motivation. In studying a subject where the source materials can be sketchy at best and might well be biased: it is the informed exploration and elucidation of intention, and the care with which this path is walked, which is the strength of the book and evokes that ever-present sense of authority.

The author's tone is never dull. Given the extent and, at times, complexity of the inter-relations between feuding and allied states, the reading is not turgid. Robin Waterfield's dry asides leaven moments of concentration and there are occasions when metaphor takes over, for example when 'terror and starvation stalked the streets of Athens' produces a rather striking and curiously poetic moment. For me the work was reminiscent of Winston Churchill's History of the English Speaking Peoples in style. This particularly showed itself at moments of historic tension, in the pithy final sentence of a chapter, as for example, 'The delusory nature of such dreams would rapidly be exposed' at the end of the chapter on The Macedonian Conquest. This foreshadowing by our omniscient author keeps the chapters rolling.

The question for me is: what kind of book is this, and what is its place in the arsenal of a Classics teacher? It is without doubt authoritative. It is a book with intriguing asides and ideas to add to lessons. There are also a number of sources cited which one could employ to explore the extent to which we can reconstruct history and emotions from source material.

The volume is certainly not unreadable for a capable Classics A-level student and sections would likely appeal. It is not, in my view, however, as some reviewers have stated, a text book, per se. Anyone with an interest in the subject area could find things of use and of delight, informed, as it is by the progress in 'every field of Classical and ancient historical studies' (p. x). To me this history fits well into Robin Waterfield's own description of Polybius, the historian 'For Polybius, the mere chronicling of events was not enough: events demand an explanation ...' and it is this that Robin Waterfield amply and consummately provides.

\section{Chlö̈ Barnett, Bishop Luffa School}
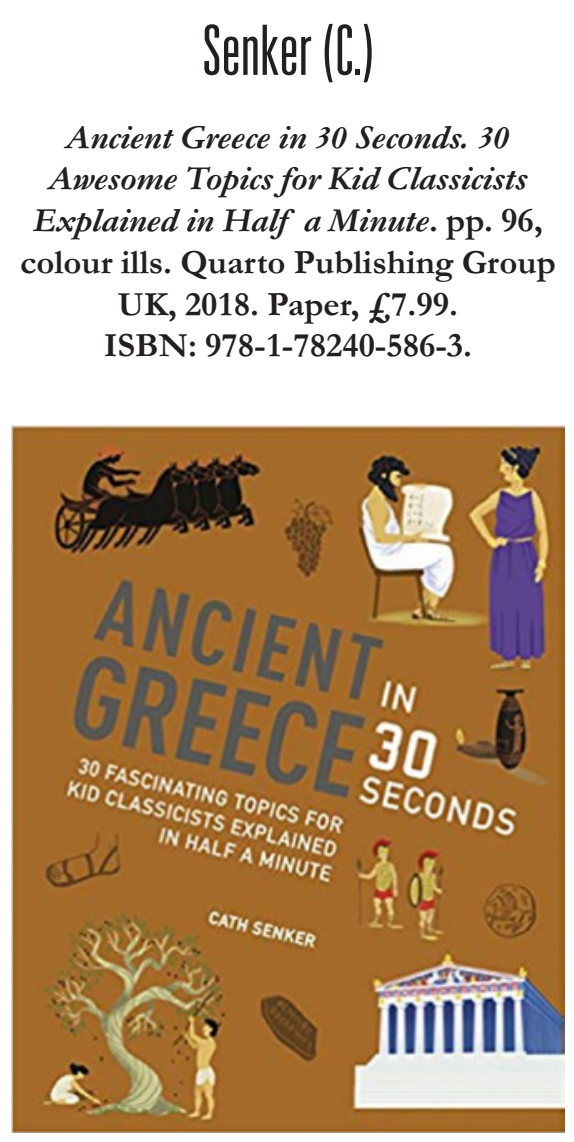

Although the title of this book may give the impression that it covers its subject matter in limited detail, this is in fact a wide-ranging, informative introduction to the ancient Greek world.
The book is divided into six sections: 'Ancient Greek Society', 'Home Life', 'Education and Work', 'Religion and Festivals', 'Architecture, Arts and Science', and 'War and the End of the Golden Age'. Each section begins with a title page and a glossary, and then contains a number of double-page spreads, each of which covers a more specific topic. The double-page spreads follow a consistent format throughout the book. The left-hand page provides a short, written introduction to the topic; it is these texts that give the book its name, as they are intended to be read 'in 30 seconds', although they may in fact require a little longer. This page also contains either a fact-box or a '3-minute mission', the latter of which either encourages further exploration of and reflection on the page's topic or sets a practical challenge to give a sense of life in ancient Greece. These challenges include writing a letter, making pancakes and carving a bust from a bar of soap, and often wisely include an 'adult helper' as one of the items necessary to complete the task. The same page also includes a '3-second sum-up' - a sentence which summarises the main message of the double-page spread. The right-hand page is an illustration-based 'colourful at-a-glance guide' (p. 7) to the topic, with some text included, and provides information to supplement what has been read on the left-hand page.

The book principally focuses on the experience of living in Greece - including such topics as 'Greek clothes', 'Farming the land' and 'Food and feasts' - rather than a narrative of 'what happened' in Greece, although some key incidents from history are discussed, chiefly in the final section where the topic 'Ancient Greece at war' (covering the Persian invasions and the Peloponnesian War) is joined by those on 'Alexander the Great' and 'The Hellenistic Age'. Although there are some references to earlier and later, the book mainly addresses what it calls the 'Golden Age' 'from around $480 \mathrm{BCE}$ to around 330 BCE, when Greek culture thrived ...' (p. 11 and elsewhere). By the end of the book one has a rich sense of life in ancient Greece, with topics such as 'Athens: rule by the people' and 'The Olympic Games' joined by others such as 'Children: toil and toys' and 'Off to market', ensuring that presentation of some of the most famous features of ancient Greece is accompanied by consideration of everyday life. The 
book does not shy away from the complexities of the Greek world. It is made clear from the outset, for example, that ancient Greeks lived not only in 'Greece' but also in many other locations around the Mediterranean (even if it is only, inevitably, Athens and Sparta which subsequently receive much discussion), and in the 'Great Thinkers' topic, Plato's story of the Cave is presented (in cartoon form). The final double-page spread concerns itself with 'What did the Greeks do for us?', which brings together many ideas raised in the book while also prompting reflection on the legacy of ancient Greece.

The book is visually impressive, with colour drawings throughout which help to bring each topic to life. These sometimes include versions of recognisable ancient objects (for example the Minoan 'bullleaping' fresco from Knossos) and maps, but often are imagined scenes in a distinctive, clear style. Although there are no photographs in the book to show what remains of ancient Greece today, the excellent, vibrant illustrations help the reader to imagine how ancient Greece might once have appeared.

There are very few errors in this well-produced book, although the spelling 'bouleterion' (p. 21 and p. 68), and the suggestion that the Parthenon's outer frieze of triglyphs and metopes shows 'the procession of worshippers to the temple' (p. 57) have made it into print. There also seems to be a discrepancy between the information given in the 'Festivals' topic and that given in 'At the theatre': in the former we read of the festival of Dionysus that 'all citizens attended - probably women as well as men' (p. 58), whilst in the latter we are told that 'the majority of the audience were men, as women were discouraged from going out in public' (p. 76) - each statement therefore giving a rather different impression of life in ancient Greece. These are, however, rare examples which do not really detract from the excellent information presented throughout the book.

The language used in the book is accessible, and often quite complex topics are distilled into straightforward summaries. The book is therefore eminently suitable as an introduction to ancient Greece for its intended audience of 'kid classicists', but older readers will find much to delight them within its pages too. Those whose appetite has been whetted by its contents can refer to a
'Discover more' section which includes recommended books, DVDs and websites, but this book itself provides a stimulating overview of the Greek world which will inform and entertain its readers whether they have any prior knowledge of its subject or not. It provides an excellent overview of life in ancient Greece, and will be enjoyed for far longer than 30 seconds!

\section{James Watson}

\section{Osgood (J.)}

Rome and the Making of a World State 150 BCE - 20 CE Cambridge:

Cambridge University Press, 2018 Paper, £21.99 ISBN: 978-1-108-41319-0

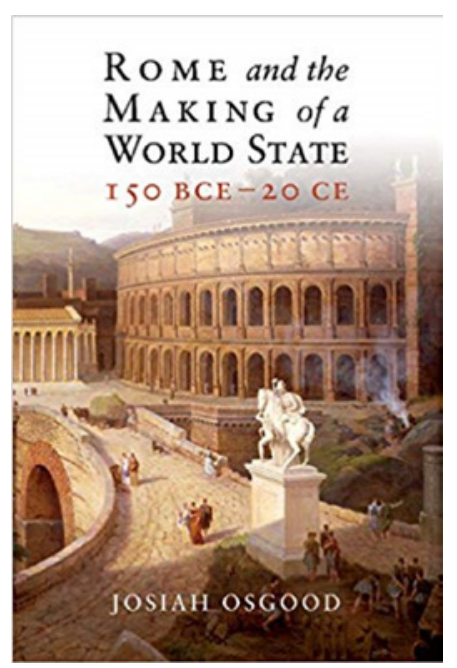

To claim, as this author does in a concise and very readable account, that the fall of the Roman Republic essentially ensured the ascent of Rome, is not new. Nevertheless, this proves to be a worthwhile addition to the secondary literature on a key period of European history.

The style of writing alternates between lively details and general sketches, in prose which one reviewer has characterised as 'highly journalistic'.

Indeed, Osgood's asides can be irritating: 'If [Julia] did carry on love affairs, especially after being compelled to marry Marcellus, Agrippa and then Tiberius ... who could blame her?'

Osgood tells the story of a republic which, to the accompaniment of frequent bursts of civic mayhem and bloodshed, became increasingly unable to handle the job of governance. In a particularly fine chapter, 'The Spiral of Violence, 104-80 BCE', he gives a clear picture of the vaunting careers of Marius and Sullaessential background for any student needing to understand the context of Pompey v. Caesar later on.

The author makes his handling of and attitude to source materials transparent - again, a good example for the Ancient History beginner. However, readers will need to look elsewhere for, say, any discussion of Cicero's character assassination of Mark Antony in the Philippics.

All in all, as a survey of 170 years of Rome's role in the world, this book stands up well to both the established (e.g. Scullard) and recent (e.g. Beard's SPQR) competition and can be recommended to any sixth-former who might wish to inform themselves about the period by a couple of days' reading.

\section{Giles Dawson, Freelance Classics teacher, Oxfordshive}

\section{Wallace-Hadrill (A.)}

\author{
Augustan Rome. Second Edition. \\ pp. $x x+147$, ills. London and New \\ York: Bloomsbury Academic, 2018 \\ (first published 1993). Paper. £14.99. \\ ISBN: 978-1-4725-3426-2.
}

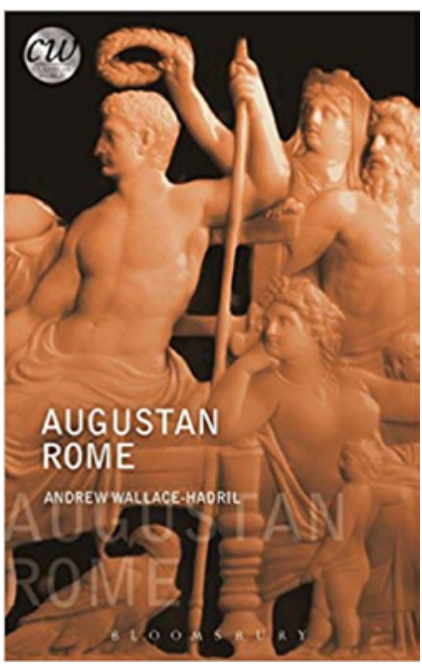

Documenting the life, legacy and associated intrigues of the man who found Rome in bricks and left it in marble is no mean feat; yet Andrew WallaceHadrill - among the world's foremost Roman cultural historians - hits pay dirt in this second edition of Augustan Rome.

First published in 1993, the original edition of this slim volume was pegged by the author as an 'interpretive essay' rather 
than a definitive account of its subject, with the express purpose (as per the preface to this new edition) of cajoling readers 'to raise questions and make connections'. As such, from the outset the intended audience is made clear - geared towards sixth form or first-year university level, Wallace-Hadrill's prose is unfussy, clearly structured, and free of the over-erudition which mars many treatises on this lofty subject, aiming to stimulate the reader to 'construct his or her own Augustus', as Augustus is 'far too complex for any one view be rated as truly authoritative'.

This approach succeeds magnificently, with effortless integration of the ample literary and archaeological evidence alongside an interpretation of the dense politics of his reign. The author's chronological scope

(31BC-14AD), encompassing 'The Myth of Actium' via his gradual

'Metamorphosis' from Octavian to Augustus, his rule and rebuilding of 'Golden Rome' and subsequent deification ('God and Man') makes it plain for the nascent scholar just how Octavian, with victory at Actium, impacted the city of Rome, its values and art.

The additions for this second edition were prompted by the author's enormous fortune to have lived in Rome at the forefront of new excavations in the Jubilee Year' of 2000 (notable for the controversial rehousing of the Ara Pacis Augustae), as well as at Nicopolis, where monuments to Augustus' victories at Actium still stand proudly - a new introduction reflects this, as does a postscript, which attempts to reassess Augustus' legacy. Updated references and reading list also reflect this explosion in new materials and methods of scholarship.

While the main body of the text remains unaltered, a new introduction helpfully surveys the myriad of both primary and secondary sources. From Horace, Virgil and Ovid through to modern interpretations from the likes of Paul Zanker, author of Power of Images in Augustan Rome (1987) and the former head of the German Archaeological Institute Edmund Buchner, who in the 1980s discovered the Horologium Augusti (the sundial made of Egyptian granite brought back from Heliopolis, recalling again the triumph of Actium). Elsewhere, WallaceHadrill rightly cites Symes' The Roman Revolution as the classic modern treatment of his subject, while Shakespeare's Julius Caesar and Antony and Cleopatra are praised for having 'extraordinary grasp as well as drama'- thus, those with no knowledge of the period may start by reading this summary; its bountiful suggestions for further reading will illuminate understanding and curiosity.

The chapters follow key ideas, intertwined with analysis of how the sources (most notably the poets Horace, Propertius and Virgil) espouse the coming of a saviour. Starting with 'The Myth of Actium', Wallace-Hadrill asserts that this decisive battle and its outcome was 'a double victory $\ldots$ as well as the naval battle, there was a propaganda battle', marking one of the key themes of this most intriguing of figures. Refreshingly throughout, the author sprinkles a dash of Symes-esque cynicism amongst his compelling commentary of Augustan images of power, ensuring an open-ended view of this strangely impenetrable character is presented. The second chapter ('Metamorphosis') neatly dissects the superhuman connotations of Octavian's transition to Augustus as he 'turned the city of Rome from a place of competition to an imperial showplace' (p.39). 'Palace and Court' (Chapter 3) looks at how rather than usurping the power of the Republican nobility, as the feted 'restorer of the old republic' Augustus took care to preserve the old families, transforming them from independent agencies to his own courtiers - while still managing to build his 'humble abode' at the summit of the Palatine Hill, next to the mythical hut of Rome's founder Romulus!

The fourth chapter ('Golden Rome') is a buoyant survey of the architecture commissioned under Augustus, which 'made the city a showpiece simultaneously of Rome's power in the word and of his own power in Rome' (p.87), lavishly illustrated with a wealth of glossy plates, including maps, plans, photographs and diagrams which neatly complement the raft of numismatics used elsewhere throughout the volume. 'Love And War' (Chapter Five) tackles the moral reform which underpinned the whole order (including the construction of the Ara Pacis), and how Augustus cannily used the cultural patronage of the era's poets to 'promote a positive image of himself in the literature of the day' (p.91). There is a seamless segue from 'Augustus the moral model' to the final chapter 'God and Man', wherein his adoption of the title Pontifex Maximus is discussed alongside the assertion that
'(Augustus) understood the enormous political potential of manipulating religious sentiment' and 'revived traditional roman religious practices and values, but in such a way as to place him at the centre of the system' (p.111).

The addition of a postscript reflecting on Augustus' legacy and reception in the 21 st century is thoughtful, and in keeping with the text's main aims; as Wallace-Hadrill tells us 'the positive and negative sides of Augustus are entwined, not merely in his personality, but in the situation he found himself confronting' (p.133), as, in spite of an occasionally dim view, the author is at pains to point out that the city of Rome prospered as never before under the new regime. A generous and full further reading section - again, thematically arranged - provides easy and welcoming access for those wishing to go beyond this marvellous 147-page 'introduction', an edition which remains vitally essential in coming to grips with the Son of a God who first presided over the vastness of the Roman Empire.

John Hayden, Head of Classical Studies, Columba College, Dunedin, New Zealand

\section{Cottam (C.), Hodgkinson (D.L.S.), Matthews (S.), Nicholas (L.), Renshaw (J.)}

OCR Ancient History AS \& A level Component 1: Greece London \& New York: Bloomsbury Academic, 2017, $£ 17.99$ ISBN: 978-1-350-01523-4

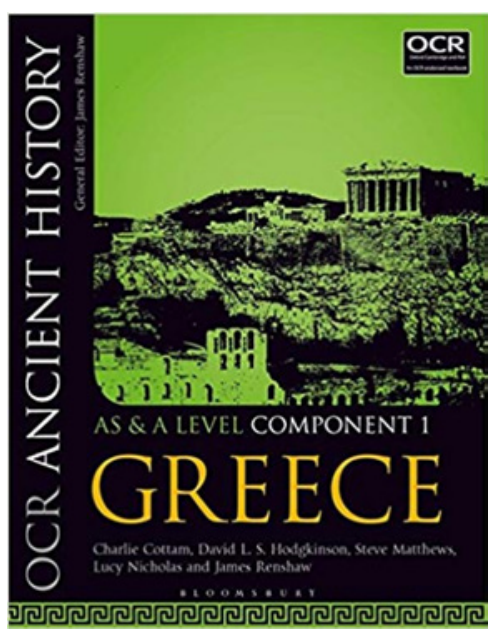

We have come a long way since Bury and Burn. Right from the start of this denselypacked textbook, the authors make salient 
points about the nature of the problems posed by Herodotus' Histories, while making no bones about what a unique and essential source it is. By way of contrast, it is good for students to be made aware of what survives of the tombs of Darius and Xerxes at Naqs-e Rustam, including the statement of Darius' ideology.

Throughout the book, the 'PS' (Prescribed Sources) icon is used frequently, with the expressed and laudable purpose of keeping the student clued-up on Herodotus, Thucydides and other Greek literary sources, plus a variety of Persian material which has only featured relatively recently at this level.

The section on the Persian invasion of 480-479 provides an excellent illustration of the authors' approach to $5^{\text {th }}$ and $4^{\text {th }}$ century BCE history. Their account of Thermopylae, Salamis, Plataea and Mycale is both clear and analytical, making it plain that there is no rigid certainty about the course of these epoch-making events and those who participated in them.

A good discussion of Diodorus Siculus and Plutarch as sources for the mid- $5^{\text {th }}$ century opens chapter 1.2; later in this section, it is pleasing to note the consideration of Harpokration, commenting on an assertion by Theopompus that the Peace of Callias was a forgery designed to keep up Athenian spirits at a time of relative decline.

3.1, opening the second of the three Depth Studies, is an especially fine chapter on Athenian political and social culture. Prescribed sources include as many as eight authors, each of whose work is briefly but helpfully characterised. Impressive too is the coverage, in Depth Study 3, of the major events of Alexander the Great's career, and their significance. Again, a wide variety of both literary and material culture sources is brought into play.

Technical vocabulary (e.g. archon, demagogue, hegemony) is concisely explained in marginal boxes. Study Questions are impressive in their rigour, e.g. 'Compare the accounts of Diodorus and Plutarch mentioned here. How plausible does Plutarch's description of Aristeides sound in comparison to that of Diodorus?'. Each chapter concludes with Practice Questions, worded in the style that exam candidates can expect.

Stretch \& Challenge questions live up to their title, e.g. 'With reference to the modern writers who consider Thucydides' methodology, how far was Thucydides a revisionist?'; though students might like to know about Burrow's $A$ History of Histories, absent from the Further Reading lists in this book.

It hardly needs saying that students could not attempt the OCR Ancient History A-level without making this volume a key part of their studies. It will leave them in no doubt of the $21^{\text {st }}$ century demands of the subject, and of the high standard of exposition maintained by the five co-authors.

Giles Dawson, Freelance Classics teacher, Oxfordshive

\section{Cromarty (R.), Harrison (J.), Matthews (S.) (edd.)}

OCR Ancient History AS and A level Component 2: Rome London \& New York: Bloomsbury Academic, 2017. Paper, £17.99 ISBN: 978-1-350-01527-2

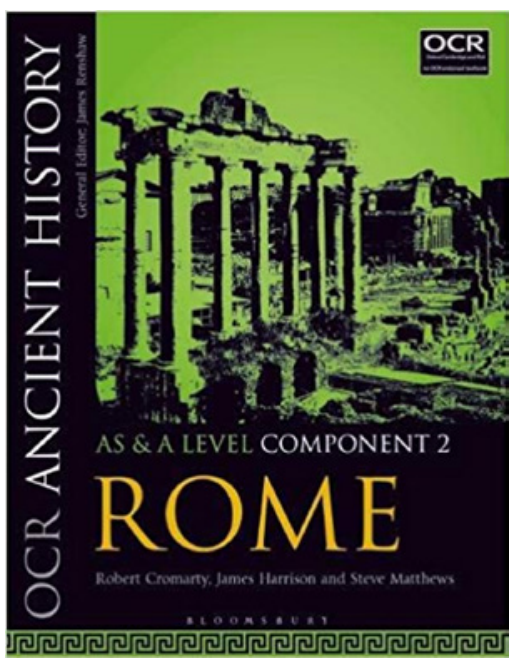

OCR with Bloomsbury have been prompt in publishing well-written and denselypacked guides to the Ancient History specifications which began to be taught from September 2017.

Before getting stuck into the (compulsory) Part 1 - Julio-Claudian emperors, 31 BC - AD 68' - readers are provided with a helpful double-page spread map of the rapidly growing Roman empire. Given the scope and quality of the text which follows, they can be sure of gaining a lively appreciation of how the empire came to be so extensive over the course of the Julio-Claudian and Flavian periods.

An impressive twelve very varied authors' work serves as prescribed sources for Augustus alone. It is good to find four odes of Horace and extracts from Ovid's Fasti alongside Tacitus and the first emperor's own Res Gestae - not to mention a wide range of relevant inscriptions and coins. This textbook adopts a ground-breaking format, in displaying and explaining individual items from the material culture as being just as worthy of close study as the better known and more obvious literary sources.

So as well as breaking new ground in actually providing a dedicated textbook for A-level Ancient History, the authors go into laudable detail in explain the significance of each chosen source.

Depth Studies (a choice of three) have been well chosen and defined. One might fairly expect 'The breakdown of the late Republic, 88-31 BC' to prove the most popular choice. Here it is given very thorough and clear treatment, punctuated by suggestions for debate - another textbook innovation for this subject/ level - with useful references to recent scholarship as well as established secondary authorities. An invitation to criticise an article on 'Aristocrats and Agriculture' in JRS for 2008 suggests the adoption of a university-level approach providing 'stretch and challenge' indeed.

For the 'Ruling Roman Britain' Depth Study, students are wisely advised to handle Tacitus' Agricola with care, whilst the likelihood of its basic factual accuracy is acknowledged. Teachers and students who go for this option will of course benefit from the sheer accessibility of many archaeological and material sources.

Technical terms are adequately explained in marginal boxed format, as also in the 'Greece' book. However, this 'Rome' volume has not been so carefully proof-read as its companion (what, for example, might 'poor-planning' be?) but fortunately not so badly as to mislead the reader or put him/her off.

It would be impossible to imagine a student now tackling OCR A-level Ancient History without relying on this comprehensive guide to the subjectmatter of Component 2. It would also be difficult to conceive of a better job being made, at this price, of providing an appropriate guide to this fascinating period.

Giles Dawson, Freelance Classics teacher, Oxfordshive 


\section{Dolansky (F.) and Raucci (S.)}

\section{Rome: A Sourcebook on the Ancient City Continuum Publishing}

Corporation (2018) Paper: pp. 272. ISBN-13: 978-1441194190

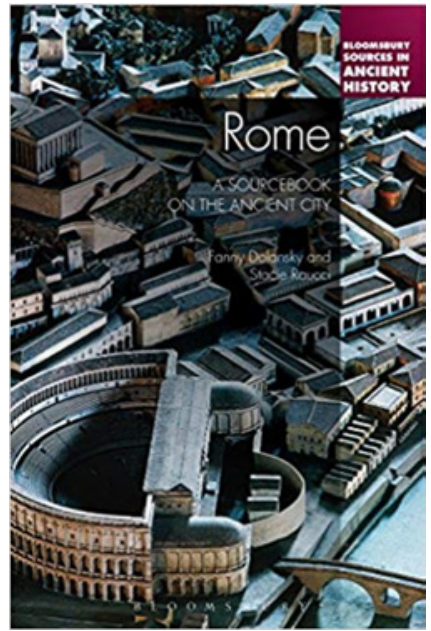

Dolansky and Raucci see this sourcebook as being placed 'at the intersection of topography, social history and culture'. It explores the physical attributes of the city; the sewers, insulae blocks, grand porticoes and temples. It also stimulates the modern imagination through its description of the sounds and smells of Ancient Rome and it places the city within the Roman psyche. Its scope is extensive and, whilst the authors acknowledge that they can't cover all sources on the ancient city, it certainly provides a significant overview.

The sourcebook brings together a range of literary and epigraphical source material, the majority of which comes from the late republican and early imperial periods. It is organised by themes rather than by geographical regions so that the sites discussed are placed in the context of the lived experience of Rome's inhabitants. Each chapter is subdivided and clear headings make it easy to search for sources on specific aspects of the city. Furthermore, each subsection is given an introduction, as well as suggestions for further secondary scholarship. This makes the sourcebook accessible and easily navigable, particularly for students at both school and university level. However, this format of organisation means that the development of the city over time and the chronology of the sources is not always made clear and could lead to confusion for those readers who are not familiar with Roman history and literature.
Chapter one positions the city of Rome within the psyche of the Romans and charts the mythical founding of the city. Chapter two explores what the city was like to live in. Quotes from Horace, Quintilian and Juvenal, amongst others, are used to build up a sense of the sounds and smells that surrounded Rome's inhabitants. Details of the different types of housing available, including details of how one would rent an apartment, are also given. Chapter eight gives a comprehensive overview of the infrastructure of Rome, from the aqueducts, sewer system and latrines to the roads, bridges and walls of the city.

Several chapters are devoted to the different aspects of Roman life: commerce and leisure (chapter three), entertainment (chapter five), religion (chapter six), politics (chapter seven), the triumph (chapter nine), and death (chapter eleven). Chapter four looks at the differences in the city between the hours of daylight and night and the various disasters that plagued Rome - fires, floods, epidemics and grain shortages - are discussed in chapter ten.

The sourcebook presents the city of Rome as a living organism that is as fascinating as the people who lived in it. It is a useful and valuable tool for anyone interested in understanding the lives of those who lived in ancient Rome.

\section{Jessica Dixon, London Oratory School}

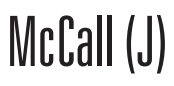

Clan Fabius, Defenders of Rome: A History of the Republic's Most Illustrious Family Pen \& Sword

(History) Publishing, 2018. Hardback, $£ 19.99$ ISBN 978-1-4738-8561-5

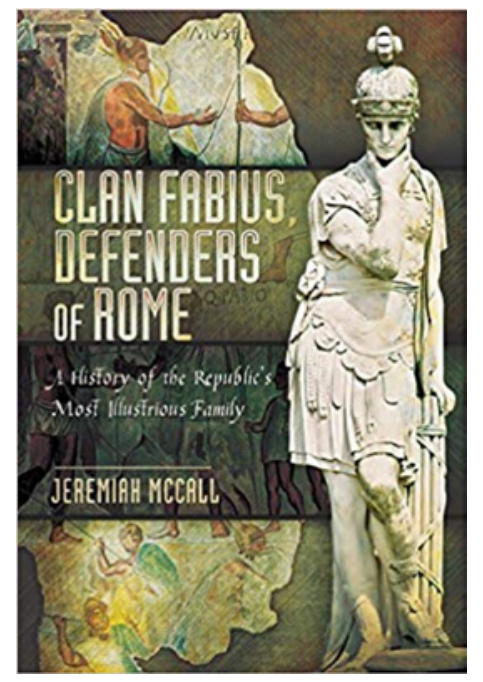

Pen \& Sword is a publishing house specialising in matters military and McCall, a classroom teacher in the U.S.A., also seems to specialise in that area. The book might seem overpriced, but is available, considerably cheaper, online, and in both ePub and Kindle format. An introductory chapter underlines inter alia the difficulties of making sense of early Roman history and of reconciling our sources, mainly Livy, Diodorus and Dionysius of Halicarnassus, to a coherent account. That said, McCall is adept at suggesting logical solutions to knotty problems of interpretation nor does he let them interfere with his running narrative. $\mathrm{He}$ is particularly good on the legendary battle of Cremera, where the whole clan was - almost - wiped out and on the later battle of Sentinum; chapters 2 - 4, however, often resolve into a list of events, which cannot easily be freed from the historical murk in which they reside.

McCall comes into his own with Fabius Maximus Cunctator and the War against Hannibal. His writing seems to pick up pace here and one clearly feels that he is in his element. The book is written for a reader not versed in the Classics and serves its purpose admirably. The military detail, strategy and tactical nous of a whole line of Fabii will be appreciated by many readers; this is enhanced by M.'s style, a curious mixture of British and American English, both being occasionally strained and idiosyncratic. The concluding chapter confirms poor historical pickings indeed for the clan and McCall has to eke it out somewhat.

The book has four appendices: Roman Names; A Glossary of Some Technical Terms; A Glossary of Major Sources for the Republic; Online Sources of Ancient Authors in Translation (this last is an unnecessarily long list of URLs - most readers would know how to search within the three of four named websites). There is also a list of endnotes, a Bibliography (sadly, omitting all non-anglophone scholarship) and a good Index. I found only few typos, although one runs into 'Catalinus' on p. 163.

Terry Walsh, retired teacher 


\section{Potter (D.)}

Theodora. Actress. Empress. Saint. New York: Oxford University Press, 2015. ISBN 978-0190692759

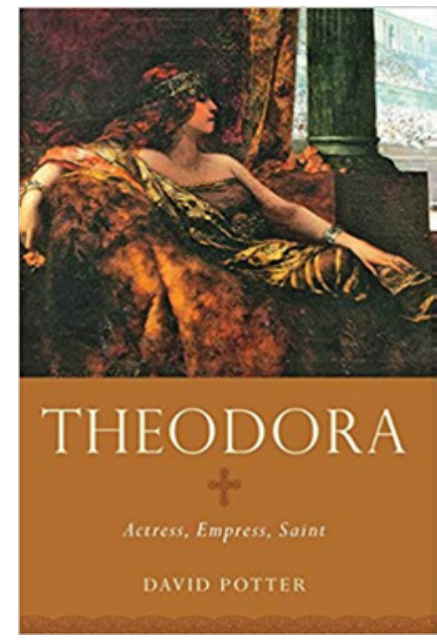

This is a very suitable and good book for Classicists aiming to extend their knowledge of the Later Roman Empire following the collapse of the West's supremacy. Potter covers a vast swathe of factual detail alongside his biography of Theodora. His analysis and tone are pointed, clear and often amusingly tongue-in-cheek making this book a pleasurable read. He engages with history, religion, culture, the rich and poor of society, men and women, foreign and domestic affairs richly. His portrayal of Theodora is attractive, sophisticated, touching and fair. We follow her unplanned Odysseus-esque journey across the eastern Roman world from life as an actress to becoming empress. During this journey Potter engages with the position of actors and actresses and the nature of entertainment in the Later Roman Empire from drama to circus performances. He discusses the harsh lives of actresses and the position of prostitution with sensitivity showing how the laws of the empire (pp.39f.) were designed to curtail their freedoms and prevent social ascent (pp.46f.). Nonetheless he is realistic, pointing out how these families were not starving and lived relatively well (p.12). Once enthroned, Potter shows how the other, richer half lived with analyses of life in court (pp.123f.).

Architecture, ceremony and bureaucracy are covered on pp.107-122. Similarly, he provides insights into the importance of the chariot race teams (reds, blues, whites etc.) and the power which these teams (or rather gangs would be a better word) controlled people and society itself through rivalry and riots (Chapters Four and Eight passim). Both of these discussions, although focused upon the Fifth and Sixth Centuries A.D. are invaluable reading for Latin teachers as much of the content provides interesting background to how chariot racing and drama worked in the Roman world (Chapters Three and Four passim). Of further interest are his explanations of the theological debates which were at the centre of so much of the politics of the time (pp.18-22) and his details about contraception (pp.50ff.). Theodora's own influence upon politics is considered throughout; however of great note are Potter's details about her sponsorship of relief for prostitutes (pp.55-57; 136-138; 180-183).

Historiography with consideration of sources is scholarly as are his thoughts about Theodora's legacy and reception. His footnotes and bibliography are thorough, providing opportunity for further reading. His index, timeline, maps, images and, most importantly, dramatis personae are all greatly appreciated and helpful. It should be said that, although suitable for precocious sixth formers, sections (e.g. Chapter Two) are quite racy.

\section{A.K.J. Carroll, Saint Olave's Grammar School, Kent}

\section{Neumann (J.)}

A Companion to Roma Aeterna Indianapolis; Cambridge 2017. £29 ISBN: 978-1585108411
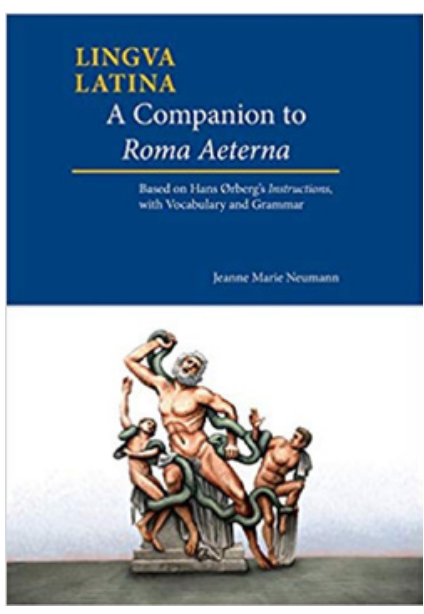

This is a guide, 463 pages in length, to the second volume of a Latin course of some
424 pages. Roma Aeterna, together with Familia Romana, forms a complete Latin course Lingua Latina per se illustrata, designed to take learners to a level where they can read original Latin texts fluently a bold claim. Although little known in the UK, many people around the world believe it is the best Latin course. However, both volumes are written entirely in Latin, so some guidance is necessary - or is it?

The course was written by Hans $\mathrm{H}$. Orberg, a Danish grammar school teacher of English, French and Latin. He wondered why his experience of teaching Latin seemed so ineffective and dull compared with his teaching of English and French. He spent the rest of his life developing a course which uses many of the techniques employed by MFL teachers and which recent research into learning shows are effective. The concept of his course is that the meaning of all new vocabulary and features of the language can be understood from the immediate contexts in which they are introduced. The series' title, Lingua Latina per se illustrata, refers to this, where some words are given a meaning by picture, some by definition in Latin by reference to words already known, and others can only have one meaning in their context.

Familia Romana introduces all the accidence and virtually all basic syntax of Latin, together with a good working vocabulary of 1800 words. It is more than sufficient as a basis from which to tackle unadapted Latin. Roma Aeterna adds more detailed Latin usages, and expands the known vocabulary to 3,000 words. The aim is to provide sufficiently extensive practice in reading Latin to promote fluency in reading original Latin texts. The texts are all based on Roman authors but simplified (less so as the book progresses) Virgil (early books of the Aeneid), Livy, Sallust and Cicero.

Why a companion in English at all? Ørberg provided a very short guide to his course, so unless you are a purist, dedicated to sticking exclusively in the target language, guidance in ones' own language is useful. Neumann takes this Orberg's guidance as her starting point - indeed she includes all of his very brief guidance - and adds a great deal more analysis and explanation of her own. She writes (often at some length) about new grammar; she goes into the detail in the manner of 'spiral' curriculum, both for grammar and vocabulary; she talks 
through word usage; and she explains more generally points of style, such as word order and differences between Latin and English idiom. These are all the sorts of things a teacher will want to touch on in various ways in the classroom. A lot of the explanations are very good, and reveal a skilled, experienced teacher who has a deep understanding of Latin and a knack of explaining things in a way that makes them clear and logical. There is also great value in seeing explanations from the different tradition that the U.S. has. There is a lot of comparison and bringing things together - for example the seven ways Latin has for expressing purpose. These are also illustrated by many examples, some from the first book Familia Romana. For example, a section on purpose clauses has 30 examples taken from Ørberg's text. There is a lot of wisdom in this approach if one's aim is to encourage fluency in reading.

Roma Aeterna does not have to be worked though from cover to cover. This means that some repetition is inevitable in any companion. Neumann strikes a good balance between cross-referencing and having each chapter standing alone. She occasionally cross-references forward which might be off-putting to some. She adopts a general scheme for each chapter of five sections: new syntax; expansion of previous syntax; explanation of words and phrases; review; and points of style. As the book progresses, the first two sections are not needed to any great extent. The accuracy of her explanations of the text is good. The occasional macron has gone awry but this is unlikely to confuse most users. The presentation is also clear, with enough space on each page to avoid the text appearing too dense and uninviting. The list of vocabulary for each chapter is helpfully listed by parts of speech and within these alphabetically. It would have been even more helpful if the third declension nouns had been grouped by gender.

For some, the explanations might be too full. The North American tradition employs descriptive analysis and use of technical terms to a greater extent than we are used to in the U.K. and for students in the latter tradition, it may prove counterproductive rather than helpful. It also rather goes against the spirit of the course which is that the Latin passages are best understood from within the language rather than described and explained from another language (such as English). Of course, this is an ideal, as Ørberg realised when he wrote his succinct guide in English. Neumann's guide goes a lot further.

So is this guide useful? The course is used by many teachers in schools and colleges in the U.S. and in Europe. For those who want to teach Latin via Latin this book is of less use. Indeed, in a lecture at a conference in February 2018, Living Latin in New York City ${ }^{1}$, Nancy Llewellyn stated that using a companion to the course had put her teaching back three years because it had taken her students out of the target language.

The book is certainly useful for those who teach in a more traditional way, but the detail is likely to be too much for most students who are seeing the material for the first time. However, for those who want to recharge their language, or who want to increase the fluency of their reading this book has much to offer. Experience has shown that those who have a decent grasp of Latin can profit greatly from working through Roma Aeterna, and having this companion to hand would make the process more enlightening.

\section{Clive Letchford, University of Warwick}

\section{Nicholson (M.)}

Museum Mystery Squad and the Case of the Roman Riddle. pp 143, ills.

Edinburgh: Floris Books, 2018. Paper. f5.00, US\$ 6.95. ISBN: 978-178250-364-4

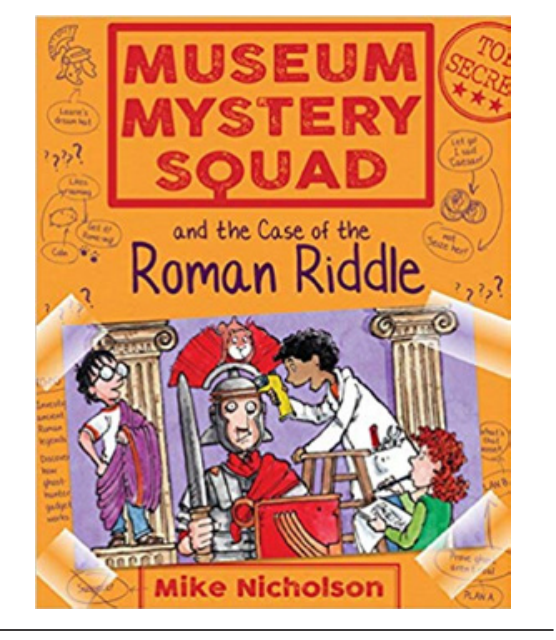

${ }^{1}$ https://medium.com/in-medias-res/ in-or-out-of-oerberg-217997ec1ad5, accessed 29 January 2019
This lively adventure story is excellent for primary pupils. At 139 pages of large type it can be read aloud in an hour and a quarter and is readily accessible for individual young readers too. My own 7 -year-old was sufficiently impressed that he asked to read the book for himself again, having been read it by me. The story continues the adventures of the 'Museum Mystery Squad', a band of three intrepid children and their obligatory pet sidekick in the National Museum of Scotland.

The stories cohere around items from the particular area of the museum where the Mystery Squad's adventures take place: in this case, the Roman galleries. The tale itself is lively, silly and thoroughly entertaining for children of no more than ten, featuring as it does a reported ghost, a professional ghost hunter and a variety of entertaining characters. Over the course of the story children are introduced to concepts such as treasure trove, items that might be found in the pertinent section of the museum, and so on. This is a lovely example of gentle education through stealth and context, rather than the 'factual' books that primary children are subjected to as part of reading schemes.

Aside from the actual narrative of the story, factual information is also presented in a lively, entertaining way with quizzes, fact-files and word searches at the end of a number of chapters. Mike Phillips' excellent cartoon illustrations are huge fun and add to the general entertainment and accessibility of the book.

As a Classics teacher, one small disappointment for me was the translation of esse as 'here', which, although thoroughly believable, (garnered in the plot, as it was from an internet translation site) was, I felt, unnecessary given the quality and educational value of the rest of the book.

Chlö̈ Barnett, Bishop Luffa School 